\title{
A model for archaeologically relevant Holocene climate impacts in the Aegean-Levantine region (easternmost Mediterranean)
}

\author{
Eelco J. Rohling1,2, Gianluca Marino ${ }^{1,3}$, Katharine M. Grant ${ }^{1}$, Paul A. Mayewski ${ }^{4}$, and \\ Bernhard Weninger ${ }^{5}$ \\ 1. Research School of Earth Sciences, The Australian National University, Canberra, ACT, 2601, Australia. \\ 2. Ocean and Earth Science, University of Southampton, National Oceanography Centre, Southampton \\ S014 3ZH, UK. \\ 3. Department of Marine Geosciences and Territorial Planning, University of Vigo, 36310 Vigo, Spain. \\ 4. Climate Change Institute, University of Maine, Orono, USA. \\ 5. Institut für Ur- und Frühgeschichte, Universität zu Köln, Weyertal 125, D-50931 Köln, Germany.
}

Abstract. A repeating pattern of multi-centennial-scale Holocene climate events has been widely (globally) documented, and they were termed Rapid Climate Change (RCC) events. Non-seasalt potassium ion $\left(\mathrm{K}^{+}\right)$series in Greenland ice cores provide wellconstrained timings for the events, and a direct timing relationship has been inferred between these events and the frequency of northerly cold polar/continental air outbreaks over the eastern Mediterranean Sea through gaps in the mountain ranges along the northern margin of the basin. There also appears to be a remarkable timing agreement with major archaeological turnover events in the Aegean/Levantine region. Yet no physically consistent assessment exists for understanding the regional climatic impacts of the events around this critical region. We present a simple 2-dimensional Lagrangian model, which yields a broad suite of physically coherent simulations of the impacts of frequency changes in winter-time northerly air outbreaks over the Aegean/Levantine region. We validate this with existing reconstructions from palaeoclimate proxy data, with emphasis on well-validated sea-surface temperature reconstructions and a highly resolved cave speleothem stable oxygen isotope record from Lebanon. Given that the RCCs were clearly marked by negative sea surface temperature anomalies in the region, we find that the predominant climatic impacts of this winter-time mechanism were "cold and wet," in contrast with intercalated "warmer and more arid" conditions of non-RCC periods. More specifically, the RCCs are found to be periods of highly variable conditions, with an overall tendency toward cold and wet conditions with potential for flash flooding and for episodic snow-cover at low altitudes, at least in the lower-altitude (lower 1 to $1.5 \mathrm{~km}$ ) regions of Crete and the Levant. The modelled winter-anomaly process cannot address underlying longer-term, astronomically forced trends, or the relatively warm and arid anomalies in between RCCs. The latter require further study, for example with respect to potential (summertime?) extension of evaporative subtropical conditions over the region. Finally, our results imply that the "amount effect" observed in Levantine cave $\delta^{18} 0$ (and precipitation or drip-water $\delta^{18} 0$ ) may not reflect the conventional concept related to temperature-dependent fractionation and Rayleigh distillation. Instead, it appears to arise from a complex and somewhat counter-intuitive mixing, in shifting proportionalities, between advected (external) and evaporated (Mediterranean) moisture.

Keywords. Holocene, Palaeoclimate Modelling, Middle East 


\section{INTRODUCTION}

A series of globally widespread climate anomalies occurred during the Holocene, namely the Holocene "Rapid Climate Change" events (RCCs), focussed on 9-8 ka BP, 6-5 ka BP, 4.2-3.8 ka BP, 3.5-2.5 ka BP, 1.2-1.0 ka BP, and 0.6-0.15 ka BP (the Little Ice Age; LIA) (Mayewski et al., 2004 and references therein). These events, dated with the precise Greenland ice-core chronologies, were characterised by chemical signatures in Greenland ice cores, notably non-seasalt (nss) $\mathrm{K}^{+}$increases, which have been correlated to intensified Siberian High (pressure) conditions in winter/early spring (Mayewski et al., 1997; Meeker and Mayewski, 2002; O'Brien et al., 1995). The very brief 4.2-3.8 ka BP and 1.2-1.0 ka BP events form exceptions to this relationship with nssK ${ }^{+}$increases, and thus seem to be different from the other, longer events. Note that all ages discussed in this paper are calibrated ages referenced as Before Present, where Present is the year 1950.

The main RCCs are distinctly expressed in the eastern Mediterranean Sea, showing up as $\sim 2{ }^{\circ} \mathrm{C}$ (up to $3{ }^{\circ} \mathrm{C}$ ) "cold spells" in Aegean and Adriatic sea surface temperature (SST) records at 8.6-8.0 (or 7.8) ka BP, 6-5.2 ka BP, 3.1-2.9 ka BP, and the LIA (Rohling et al., 1997; Casford et al., 2001, 2003; Mercone et al., 2001; Rohling et al., 2002a,b, 2009; Clare et al., 2008; Marino et al., 2009; Clare, 2016; Gogou et al., 2016). Given the vast heat capacity of water relative to overlying air, such multi-centennial (long-term) mean cooling of the $\sim 100 \mathrm{~m}$ thick surface mixed layer implies intense atmospheric forcing. This inference is further strengthened by deep-water data, from the same samples as the surface-cooling data, which suggest that even deep-water circulation was affected (intensified) at these times (Rohling et al., 1997; Rohling et al., 2002a; Kuhnt et al., 2007; Abu-Zied et al., 2008; Schmiedl et al., 2010).

Previous work (e.g., Rohling et al., 2002b; Casford et al., 2003; Clare et al., 2008; Weninger et al., 2009, 2014) has sought to relate the distinct eastern Mediterranean RCC signals to processes that involve the Siberian High intensifications indicated by consistent Greenland ice-core nssK ${ }^{+}$enrichments (O'Brien et al., 1995; Mayewski et al., 2004; Muschitiello et al., 2013), but debate remains about the underlying atmospheric dynamics (see section 2.1). In any case, the critical component for the eastern Mediterranean was found to consist of increases in the frequency and/or intensity of cold northerly polar/continental (NPC) air outbreaks over the sea that are channelled through gaps in the mountain ranges along the basin's northern margin (section 2.1). So far, no physically consistent assessments exist for the regional climatic impacts of the RCCs, despite the fact that understanding of these events is of central importance for studies concerning vulnerability and response of prehistoric societies to climate and environmental change in the wider Mediterranean region (e.g., Anderson et al., 2007; Biehl and Nieuwenhuyse, 2016; Budja, 2007, 2015; Weiberg et al., 2016; Weiss, 2000; 2017) (section 2.4).

This study first reviews modern and past expressions of wintertime cold polar/continental air outbreaks from the north over the Aegean Sea, and then develops a physically coherent 2-dimensional Lagrangian assessment of the inferred RCC relationships over the Aegean/eastern Levantine region. This assessment is used to quantify the expected signals of the processes involved, and finally the expected signals are compared with palaeoclimatological records through the Holocene RCC intervals. 


\section{BACKGROUND \\ 2.1. Instrumentally documented events}

Individual wintertime NPC air outbreaks from higher latitudes over the Aegean Sea and into the Levantine region have been well documented during the instrumental era (Mariolopoulos, 1961; Theocharis, 1989; Roether et al., 1996; Poulos et al., 1997; Maheras et al., 1999; Lolis et al., 2002; Tolika et al., 2014; Anagnostopoulou et al., 2017). No NPC air outbreaks occur during the summer months (Saaroni et al., 1996). In winter, North African subtropical conditions are displaced southward (Lionello et al., 2006; Rohling et al., 2015), allowing a general southward expansion of westerly, moist temperate airflows, as well as occasional atmospheric blocking patterns that drive cold and dry polar/continental air outbreaks from the North (e.g., Tolika et al., 2014). Over the central and eastern Mediterranean Sea, low surface-pressure conditions persist even during these outbreaks because the sea's high thermal capacity maintains a contrast between relatively high sea-surface temperatures and the colder surrounding landmasses (Lolis et al., 2002).

The main drivers for winter-time heat loss from the Mediterranean are the so-called "East Atlantic" and "East Atlantic/West Russian" (EA and EA/WR) atmospheric circulation modes (Josey et al., 2011), when Mediterranean low-pressure conditions interact with a north-eastward extension of the Azores High (over Iberia, France, and southern Britain), and/or westward ridging of the Siberian High towards North-West Europe and southern Scandinavia (Maheras et al., 1999; Lolis et al., 2002; Tolika et al., 2014). During the EA or EA/WR modes, intense northerly flows of cold and dry air masses toward the Mediterranean basin are channelled through valleys in the mountainous topography of the basin's northern margin. In the eastern Mediterranean, channelling occurs through river valleys-such as that of the Axios (Vardar zone), Strimon, and Evros-towards the Adriatic and Aegean Seas, where it gives rise to the "Bora" and "Vardar" winds, respectively.

The atmospheric dynamical configurations that underpin persistent Aegean cooling events over decadal to centennial scales remain subject to debate. They have been ascribed to a number of patterns. The first invokes frequent protrusion of a polar trough into the Mediterranean region, favoured by northward extension of the Azores High toward Iceland or Greenland-blocking moisture supply by the westerlies-and further enhanced by expansion and intensification of the Siberian High in winter during glacial times (Kuhlemann et al., 2008). Luterbacher et al. (2006) find that the most important Mediterranean cold pattern corresponds to a blocking configuration with easterly to northeasterly airflow towards the Mediterranean, and that cooler and wetter conditions in the last decades of the seventeenth century coincided with and increase in the surface Russian High pressure influence, which caused easterly dry and cold airflow to advance further to the west, The second pattern involves a multicentennial reduction in the northward heat transport by the North Atlantic subpolar gyre, with internal climate feedbacks-notably increases in Scandinavian blocking event frequency-causing winter amplification of the European Little Ice Age cooling (Moreno-Chamarro et al., 2017). The third suggested pattern concerns a positive state of the EA/WR pattern that results in strongly enhanced heat loss over the Aegean region (Josey et al., 2011), combined with positive North Atlantic Oscillation phases that lead to decreased winter precipitation, and negative Atlantic Meridional Oscillation phases that further intensify 
cooling in the Aegean region (Incarbona et al., 2016). Tolika et al. (2014) described a strong pattern for the entire, cold, winter of 2012 (hence, not just for a short event), which integrates many of the individual features discussed above. They find both intensification and northward extension of the Azores High, and-especiallywestward extension of high-pressure conditions throughout Asia (Siberian High) toward the Balkans and northern Europe. Tolika et al. (2014) infer that the latter caused blocking of the atmospheric circulation on its western side over Scandinavia, eastern Europe, and the eastern Mediterranean, which in turn favoured transfer of cold air masses from high northern latitudes over the Balkan and eastern Mediterranean. Anagnostopoulou et al. (2017) noted considerable large-scale similarities during a cold event in winter 2017. In context of the above, we view the Siberian High not as a unique driver, but as a correlated part (higher pressures correlating with intensified Aegean cooling) of wider northern hemispheric circulation modes that enhance advection of cold air from high latitudes toward the eastern Mediterranean, and which-for instance-also include deepening/shoaling of a Low between Iceland and southern Greenland (Panagiotopoulos et al., 2005; Tubi and Dayan, 2013).

Regardless of the precise underpinning dynamics, enhanced wintertime cold NPC air outbreaks cause intense evaporation and cooling of the Mediterranean Sea surface (e.g., Leaman and Schott, 1991; Saaroni et al., 1996; Poulos et al., 1997; Maheras et al., 1999; Casford et al., 2003; Josey et al., 2011; Velaoras et al., 2017). A particularly noticeable period with frequent events over the Aegean occurred in the late 1980s-early 1990s, contributing to profound changes in deep-water formation in the region (Theocharis, 1989; Roether et al., 1996). Casford et al. (2003) drew on this-along with new shipboard data for a December 2001 event-to infer the impacts of prolonged episodes with high event intensity/frequency on deep-water circulation in the Aegean-Levantine region throughout the Holocene (for indicators of Holocene deep-water changes, see Rohling et al., 2002a; Kuhnt et al., 2007; Abu-Zied et al., 2008; Schmiedl et al., 2010). Incarbona et al. (2016) similarly found a relationship within the past 500 years between multi-decadal deep-water ventilation changes in the eastern Mediterranean and surface cooling events. Deep-water ventilation records provide the most convincing means of identifying the most intense episodes of clustered events, given that climatic anomalies of considerable strength and cumulative duration are needed to intensify deep-water formation and deep-sea ventilation.

The environmental impacts of an individual cold NPC air outbreak are well illustrated by the 2001 event (Casford et al., 2003), which lasted (with variations) from December 2001 to January 2002, and was marked by high-intensity (8-9 Beaufort, or 17-25 $\mathrm{m} \mathrm{s}^{-1}$ ), freezing (down to $-2^{\circ} \mathrm{C}$ ), north-northeasterly airflow over the Aegean Sea (Casford et al., 2003; Clare et al., 2008). There was exceptional snowfall around the Aegean region, including $\sim 30 \mathrm{~cm}$ in both Istanbul and Athens (see summary in Clare et al., 2008). Temperatures in Bulgaria and northern and central-eastern Greece dropped to minima of $-20^{\circ} \mathrm{C}$, and there was widespread disruption of infrastructure and services (see summary in Clare et al., 2008). More than 300 villages in central and northern Greece became isolated, and there were many deaths from exposure (World Weather News, 2001; CNN Weather, 2001). In earlier years, 1929 and 1954, conditions became so severe that much of the Bosporus froze over (Yavuz et al., 2007). 
Finally, cold NPC air outbreaks are known to play a key role in cyclogenesis over the eastern Mediterranean, and in particular the Cyprus Low, which governs a large portion of rainfall over the Middle East. Tarolli et al. (2012) state that: "... over the Mediterranean climate areas of Israel, high precipitation events and extreme flash floods are mainly associated with the Cyprus Low, ... a winter extra-tropical cyclone ... system... (Sharon and Kutiel, 1986; Alpert et al., 1990; Krichak et al., 2004; Ziv et al., 2006; Wittenberg et al., 2007; Saaroni et al., 2010). The cold air masses gain moisture ... over warmer Mediterranean waters and become conditionally unstable. ... An upper-level trough extending toward southwestern Turkey induces cold advection aloft, enhancing cyclogenic conditions over the Cyprus Low region." Overall, therefore, the cold NPC air outbreaks were found to be critical drivers of downstream hydroclimate conditions over the lands that border the Levantine Sea, easternmost Mediterranean, during the instrumental era.

\subsection{The Little Ice Age}

Assessments of terrestrial palaeoclimate proxy records around the Mediterranean that pre-date the instrumental era have inferred notable hydroclimate variations, including arid episodes (Roberts et al., 2011; Cheng et al., 2015; Clarke et al., 2016), and some have inferred spatial hydrological contrasts (Roberts et al., 2011; Cheng et al., 2015). However, comparisons between terrestrial signals, and between terrestrial and marine signals, may be compromised by: 1) offsets/uncertainties between chronologies; 2) comparing records of different temporal resolutions (e.g., Clarke et al., 2016); 3) regionally differentiated climatic expressions (e.g., with altitude, or upstream versus downstream relative to the evaporative sea); and/or 4) inaccurate or oversimplified assumptions about processes controlling the palaeoclimate records.

One way to advance is through comparison of instrumentally documented events (above) with documentary/anecdotal evidence for the Little Ice Age (LIA) to evaluate the range of impacts of sustained cold NPC air outbreaks over the Aegean-Levantine region (e.g., Xoplaki et al., 2001; Yavuz et al., 2007; Clare et al., 2008; Clare, 2016). This reveals that instrumentally documented impacts resonate strongly with the regional LIA accounts. For example, Xoplaki et al. (2001) report that the LIA was characterised by: more cold/severe winters and springs; a significant tendency to more winter precipitation (with notable prevalence of snow, which in the year 1700 even survived through summer on the Cretan mountains); and by significantly more winter drought. In short, there was a significant increase in winter extremes, being either very cold, very wet/snowy, or very dry. A subsequent LIA compilation further supported this inference of a significant increase in winter extremes in the eastern Mediterranean region (Clare, 2016). The main synoptic situations responsible for the region's winter cold and snowfalls again involved northerly airflow, with high pressure over northern Europe and lower pressure over the central or eastern Mediterranean (Xoplaki et al., 2001).

During the LIA, glacier development/expansion occurred in many Mediterranean mountain locations, while (semi-)permanent snowfields became established in the mountains of Greece, which are too dry for glacier development (Hughes, 2014). This requires not only cold, but also moisture supply. In the Pirin Mountains, SW Bulgaria, there even was a drop in mean summer temperatures by $2-3{ }^{\circ} \mathrm{C}$ at around $1600 \mathrm{AD}$ : soil formation processes came to a halt, the snowline descended, the vegetation period 
became shortened, and snow cover persisted for longer (Grunewald and Scheithauer, 2010).

Between 1600 and 1930, frequent widespread freezing events affected the Black Sea, Bosporus, Golden Horn, and Istanbul region (Yavuz et al., 2007), and mean surface mixed-layer temperature dropped by $\sim 2{ }^{\circ} \mathrm{C}$ in the northern Aegean Sea between about 1650 and 1850 (Gogou et al., 2016). In addition, flooding frequencies and fluvial discharge were increased around the Aegean (see overview in Gogou et al., 2016), although stable oxygen isotope data from the high-altitude $(1363 \mathrm{~m})$ central Anatolian lake Nar Gö̈lu show a positive 2-3 \%o LIA anomaly that has been interpreted in terms of increased aridity (Dean et al., 2013). If correct, this might reflect a remarkable spatial and/or vertical contrast, possibly due to specific local conditions for the Anatolian highlands (e.g., increased lake evaporation into high-altitude, cold, low-humidity air under high wind speeds, see also section 5).

\subsection{Older Holocene RCCs}

Similar to the LIA, other Holocene RCCs were also associated with notable environmental changes in the Aegean-Levantine region. In this section, we illustrate the main impacts across a number of mid-to-late Holocene events. Mean terrestrial coolings of more than $4{ }^{\circ} \mathrm{C}$ have been reconstructed to the north of the Mediterranean, e.g., in NW Romania (Feurdean et al., 2008), SW Romania (Poleva Cave; Constantin et al., 2007), and-at least for the 8.2 ka BP event-in northern Greece (Pross et al., 2009). As mentioned above, all main RCCs are expressed as $\sim 2{ }^{\circ} \mathrm{C}$ (up to $3^{\circ} \mathrm{C}$ ) drops in Aegean and Adriatic sea surface temperatures (SST). Given this distinct SST signature, and the vast heat capacity of an $\sim 100$-m-thick mixed layer, much sharper and more pronounced terrestrial climatic impacts should be expected.

In view of the NPC air-outbreak mechanism behind the events, terrestrial impacts likely were highly variable in time, with considerable extremes (in marine records, such variability is smoothed out by both longer time-integration due to oceanic inertia, and multi-decadal smoothing in the sediments investigated). Rohling et al. (2009) speculated that, during the RCCs, intensified winter frosts and aridity might especially be expected upwind of the sea (along the northern and northeastern sectors of the Aegean), while milder but still anomalously cool conditions with exceptional snow- or rainfalls might be expected downwind of the evaporative sea, when air rises and cools during convection or orographic uplift. This seems to be supported by the findings of Valsecchi et al. (2012) that apparent forest retreat occurred during several of the RCC periods around the Sea of Marmara, in coincidence with sea-surface cooling noted in the same sediment core, suggesting a combination of cold and arid conditions in that location to the northeast of the Aegean Sea.

As an important aside, note that the RCC between 8.6 and $~ 8.0$ or 7.8 ka BP contains within it a sharp, short-lived event ( $\sim 150$ years; Thomas et al., 2007), from about $8.2 \mathrm{ka}$ BP. This is the so-called " $8.2 \mathrm{ka} \mathrm{BP"} \mathrm{event} \mathrm{that} \mathrm{is} \mathrm{widely} \mathrm{ascribed} \mathrm{to} \mathrm{a} \mathrm{final} \mathrm{glacial}$ meltwater outbreak into the North Atlantic from Hudson Bay (e.g., Alley et al., 1997; Barber et al., 1999). The superimposition of the $8.2 \mathrm{ka}$ BP event upon a major multicentury RCC has been well documented on a (near) global scale (Rohling and Pälike, 2005), including the Aegean region (Marino et al., 2009; Schemmel et al., 2016). Care must be taken not to confuse one with the other (see also Weninger et al., 2014). Our 
main focus here is on the recurring Holocene RCCs driven directly by changes in atmospheric circulation.

Between 8.6 and 8.0 ka BP, there definitely was Aegean-Levantine cooling, along with improved deep-water ventilation (e.g., Rohling et al., 2002a,b; Kuhnt et al., 2007; AbuZied et al., 2008; Schmiedl et al., 2010), as seen in other RCC events. To the south, African monsoon indicators suggest that the Blue Nile contribution into the eastern Mediterranean, which had reached a peak from $\sim 10.5 \mathrm{ka}$ BP (following a gradual increase that started at $\sim 12 \mathrm{ka} \mathrm{BP}$ ) started a sharp decline from $\sim 8.4 \mathrm{ka}$ BP. African monsoon conditions then became unstable: input into the eastern Mediterranean became more dominated by White Nile fluctuations and disappeared gradually, with modern-type aridity reached at around 6 to $5.5 \mathrm{ka} \mathrm{BP}$ (cf. Revel et al., 2010; and references therein). So the RCC of 8.6-8.0 ka BP was a time of remarkable change in the wider study region, when centennial-scale RCC-style conditions coincided with major change in the orbital-scale conditions. Interpreting archaeological responses as caused by one or the other may be impossible, but focussing on the specific climatic effects expected from the RCC-style overprint of this period is possible, and is attempted here.

\subsection{Archaeological importance}

RCCs have been previously linked to archaeological changes, either in terms of temporal coincidence, or even in terms of causality. In this section, we summarise some of these indications.

A first example pertains to the initial domestication of plants and animals in the Near East during the Early Holocene. Some interpret this as a slow and gradual process based on cultural (millennial) timescales (e.g., Fuller et al., 2012; Asouti and Fuller, 2013), and others see it as a rapid process over much shorter biological (decadal) timescales (e.g., Hillman and Davies, 1990; Honne and Heun, 2009; Heun et al., 2012). A recent reanalysis (Weninger, 2017) of published archaeobotanical and archaeozoological data indicates that the wild-domesticate transition (WDT) occurred (1) abruptly at around $10.2 \pm 0.2 \mathrm{ka} \mathrm{BP},(2)$ simultaneously (within given error limits) for plants and animals, and (3) synchronously with the abrupt onset of moist conditions in the Near East (Schmiedl et al., 2010; Sharifi et al. 2015). It appears that, in terms of understanding the introduction of farming and stock-breeding, past research placed too much emphasis on the Younger Dryas (YD), given that the YD ended as much as 1500 years before the WDT. Regardless, it remained poorly understood why the transition to agriculture would have coincided (within error limits) with a sharp RCC-event at $10.23 \mathrm{ka} \mathrm{BP}$, which is very apparent in the GISP2 nss K+ record (Mayewski et al., 1997). While this might be a chance coincidence, Borrell et al., (2015) reported a major cultural discontinuity at around 10.2-9.8 ka BP in Neolithic communities in most of the Northern Levant, which again coincides closely (within error limits) with this RCC-event. And a similar time-gap also exists in the Southern Levant (e.g., at Jericho; Bar-Yosef, 1986).

For the next RCC (8.6 to $\sim 8.0$ ka BP), a previous compilation of climate indicator studies throughout southeastern Europe, Anatolia, Cyprus, and the Near East was taken to suggest 'cold and arid' conditions at around 8.2 ka BP (e.g., Weninger et al., 2006). But this may have conflated cold indicators from certain regions with arid indicators from other regions (e.g., north of the Aegean Sea, or in high-altitude Anatolia, as seen also for the LIA - see section 2.2), and conflated broader (8.6 to $\sim 8.0$ ka BP) RCC conditions with 
those specific of the superimposed 'Hudson Bay event at $8.2 \mathrm{ka}$ BP. Thus, these results need to be approached with care. More recent studies suggest that the abrupt (decadalscale) onset of Neolithic expansion from Anatolia and the Near East into the Aegean coincided at a decadal scale with the RCC onset at 8.6 ka BP(e.g., Weninger et al., 2014; Horejs et al., 2015; Krauß et al., 2017). Furthermore, the abrupt (decadal-scale) Neolithic movement out of the Aegean region, both into the Adriatic and SE Europe, coincided with the end of that RCC at $8.0 \mathrm{ka}$ BP. For example, Neolithisation of large parts of the Pannonian Basin was completed within 100 years following the RCC-ending at $8.0 \mathrm{ka} \mathrm{BP}$, and-coming from the Aegean-the Neolithic reached the Iberian Peninsula and Morocco within 200 yrs of the RCC-ending at 8.0 ka BP (e.g., Linstädter et al., 2016). In addition, widespread desertion of archaeological sites occurred in the southern Levant during the 8.6-8.0 ka BP RCC-interval (Gebel, 2009; Rollefson, 2009; Zielhofer et al., 2012; Clare, 2016), and animal husbandry spread from the Levant into NE Africa in coincidence with the RCC-ending at 8.0 ka BP (cf. Kuper and Kröpelin, 2006), while painted Halaf pottery started to spread from the northern Levant throughout Mesopotamia at about the same time (e.g., Nieuwenhuyse, 2017; van der Plicht et al., 2011).

In summary, both the abrupt onset of moist conditions at around $10.2 \mathrm{ka} \mathrm{BP}$, and the return to milder climatic conditions immediately following the 8.6-8.0 ka BP RCC (e.g., Gkinis et al., 2014), are suggestive drivers of a rapid, punctuated mode of Neolithic dispersal (cf. Van Andel and Runnels, 1995; Guilaine, 2001; Fiedel and Anthony, 2003), rather than the still more widely accepted slow-and-continuous 'Neolithic Wave-ofAdvance' dispersal model based on incremental demographic growth (Ammermann and Cavalli-Sforza, 1979). Yet, as mentioned in section 2.3, it will be extremely challenging to distinguish archaeological responses to the RCC-style event from those to the wider regional, orbitally forced, climate changes at that time. From 8.0 ka BP onward, climate conditions were less affected by underlying orbital changes.

An example of post-8.0 ka BP archaeological change that coincided with an RCC concerns the end of the Copper Age in SE Europe. It coincides with the RCC-onset around $6 \mathrm{ka}$ BP, followed by a major 1000-year settlement gap in SE Europe and the Aegean until RCC-end at around 5.2 ka BP (Weninger et al., 2009). Interestingly, during the same RCC, the Ukraine experienced a major settlement expansion, which has been attributed to societal resilience of the (cold-adapted) Cucuteni-Tripolye cultural complex (Weninger and Harper, 2015). Finally, the end of the Bronze Age around the Aegean coincided closely with the regional RCC expression of 3.1-2.9 ka BP (e.g., Rohling et al., 2009; Kaniewski et al., 2010, 2017; Cline, 2014).

It appears, therefore, that there is a strong temporal relationship between RCCs in the wider eastern Mediterranean region and major archaeological changes, although-even within the Fertile Crescent (e.g., between the N- and S-Levant)—establishing such coincidences is complicated by complex interregional differences in terms of, for example, cultural trajectories, natural biodiversity, landscapes. Local socio-political processes are likely to have always modulated the diverse adaptive strategies of human societies in times of changing climate, suggesting that no generalised associations should be made between societal changes and periods of climate change (Weiberg et al., 2016). Accordingly, this study does not a-priori assume that correlation means causation, but seeks to identify why a correlation may be apparent between 
400

401

402

403

404

405

406

407

408

409

410

411

412

413

414

415

416

417

418

419

420

421

422

423

424

425

426

427

428

429

430

431

432

433

434

435

436

437

438

439

440

archaeological records and high-resolution Greenland GISP2 nss [K+] or [Na+] records, or other high-resolution records (e.g. Jeita Cave, speleothem $\delta^{18} 0$ ). In other words, we investigate whether there is a reasonable, replicable physical framework of connecting mechanism(s) that could explain the correlation, which might then be independently tested. This framework should reasonably demonstrate how variations in Greenland records could relate to local palaeoclimate records, and what the inferred process connection would imply for RCC climatic conditions at, and gradients between, different locations in the study region.

\subsection{This study}

Previously inferred climatic impacts on eastern Mediterranean climate for the RCCs remain qualitative and thus difficult to validate robustly. Even straightforward conceptual expectations for the regional impacts of cold NPC air outbreaks over the study region suggest considerable complexity. Following the Clausius-Clapeyron relationship, absolute humidity at saturation is lower in cold air than in warm air. Yet relative humidity can still be high because it relates the actual moisture content to the saturation value at a given temperature. This complicates previously generalised use of "cold and dry" associations (e.g., Valsecchi et al., 2012) because a cold air mass might hold less moisture, but may still drive considerable precipitation and/or fog when temperatures drop and/or air is uplifted. Also, relative humidity is near $100 \%$ so evaporation rates will be low at those times. In a practical sense, therefore, no particularly "dry" conditions need to be expected in regions under a cold airflow.

Things change when such an air mass flows out over a relatively warm ocean or lake surface. Then, its temperature and saturated humidity potential rise, and its relative humidity drops as a consequence. This triggers intense evaporation. In terms of evaporation potential over relatively warm, moist surfaces, therefore, the cold air mass indeed appears "dry". For example, lake levels are likely to drop. But fields and crops bound to growth in the wet season might still receive sufficient net moisture to remain productive (Rohling, 2016), and cold and frost may be more damaging for such systems.

Following transit of the air mass over water for a few days or more, its moisture content will have been increased strongly due to evaporation. When the air mass subsequently makes landfall and is cooled and/or uplifted, its relative humidity increases and (strong) precipitation may develop. This may fuel suitable conditions for plant and crop growth, or even detrimental (flash) flooding, while lake-levels are likely to rise (depending on the ratio between the lake-water and lake-catchment areas; Rohling, 2016). Meanwhile, stable $\mathrm{O}$ (and $\mathrm{H}$ ) isotope ratios of precipitation are affected by initial advection, evaporation, and both temperature fractionation and Raleigh distillation during condensation. Therefore, the overall picture is one of complex and often counterintuitive relationships that compromise straightforward interpretations of spatial trends and gradients between proxy records.

This study develops the conceptual formulations above into a first testable, reasonably quantified (signs and approximate magnitudes) template for interpretation of the key environmental expressions of changes between times with more frequent polar/continental air outbreaks over the Aegean-Levantine region (i.e., RCCs), and times with much lower frequencies of such events (i.e., times in between RCCs). For this, we present a physically coherent framework of minimal complexity in the form of a 2- 
dimensional Lagrangian model, which can be easily interrogated. The modelled expectations are first tested against increased cold NPC air outbreak frequencies, which in turn cause Aegean cooling on land and at the sea surface (e.g., Rohling et al., 2002a,b; Kotthoff et al., 2008; Josey et al., 2011; Tolika et al., 2014; Anagnostopoulou et al., 2017). For this exercise, we set the outbreak frequencies as a function of the record of GISP2 nssK ${ }^{+}$enrichments (O’Brien et al., 1995; Mayewski et al., 2004; Muschitiello et al., 2013), given that this record underlies definition of the (global) RCCs (Mayewski et al., 2004). Next, we explore responses on land, in comparison with terrestrial palaeoclimate reconstructions around the Aegean-Levantine region. Thus, albeit simplified, the model aims to address all processes relevant to the RCC problem, and can therefore reveal to what extent observed proxy signals can be explained by the RCC mechanism of cold NPC air outbreaks over the study region, and to what extent they reflect alternative/additional processes. The model's physically coherent view of regional variability may also benefit research into the impacts of climate change on early societies.

\section{MODEL}

\subsection{Modelling the impact of changing NPC air outbreak frequencies}

Here we describe only the general concepts behind our daily-resolved 2-dimensional model (Figure 1); full details are available in the pdf of the graphical MathSoft MathCad 13 code, with annotations (Appendix). We do not presume that our model comprehensively captures all processes that act in reality. Instead, it aims at developing a physically coherent view of changes in the key environmental parameters over representative distances, in idealised scenarios related to variations in the winter-time RCC mechanism of cold NPC air outbreaks over the Aegean-Levantine region.

Our model does not account for long-term, orbital-scale hydrological changes in the study region (e.g., Tzedakis, 2007; Rohling et al., 2015; Bosmans et al., 2015). It only considers anomalies relative to modern conditions through the year, related to NPC outbreaks of varying frequency during winter. Specifically, it resolves the influence of 10-day cooling and increased-wind-speed- anomalies that are superimposed upon the winter half-year of a regular (sinusoidal) annual cycle. Results are considered relative to a "control" year, which is set to be a year with 1 of these anomalies. A year with no anomalies then is milder than the control year, and years with 3 or 5 anomalies are more severe than the control year. The same cooling anomalies are applied where the airflow makes landfall (see below).

Initial air properties (which enter the Aegean region from the north) are set using an idealised sinusoidal representation of the annual cycle with air temperature $\left(T_{a}\right)$, relative humidity $(r)$, and vapour $\delta^{18} 0\left(\delta_{a}\right.$; calculated based on vapour-liquid fractionation from northern Greece rainfall $\delta^{18} 0$ ), following representative ranges of observations of 1 to $23^{\circ} \mathrm{C}, 0.45$ to 0.75 , and -22 to $-16 \%$, respectively (Climatemps.plovdiv; Climatemps.alexandroupoli; Dotsika et al., 2010). Wind speed (V) is set with a sinusoidal function that shows a double peak each year (one in summer and one in winter) over the Aegean region, between 5 and $7 \mathrm{~ms}^{-1}$ (Weatherspark). Surface absorbed insolation is set with a sinusoidal curve over a range of about 60 to $300 \mathrm{Wm}^{-2}$, based on modern values for Athens (about 50-230 Wm-2; Carletti et al., 2014) but allowing cleaner pre-anthropogenic and non-city atmospheric conditions, especially in summer. Air properties are considered within an exchange layer of thickness $D$, which 
sinusoidally cycles between $1 \mathrm{~km}$ (summer) and $1.4 \mathrm{~km}$ (winter) (within ranges reported by Dayan and Rodnizki, 1999; Seidel et al., 2012; Dayan et al., 2017), and all mean properties (e.g., air temperature, vapour pressure, density, pressure) are calculated with respect to the value of $D$ that applies at the specific moment in the seasonal cycle. Change in the settings for $D$ would need to be compensated by changes in the model's tuning parameters, which are set once for the present and then kept constant, so changes in $D$ do not materially affect our results. Vertical air displacements in the model affect air temperature by means of a simple moist adiabatic lapse rate set to $-6.5^{\circ} \mathrm{C} / \mathrm{km}$ (within the ranges given by Alpert et al., 1989; Vardavas et al., 1997; Dayan et al., 2002; note that minor changes in this value are again neutralised during tuning of the model's air uplift values to give correct "control" $P$ values-see below).

During passage over the sea, evaporation adds water from the sea into air layer $D$, with fluxes calculated in daily increments after Rohling (1999) and Rohling et al. (2004). The airstream then makes landfall at Crete, and passes over it, at which time it is uplifted by $5000 \mathrm{~m}$ during the (10-day) events of cold air outbursts over the relatively warm seas, given that this is known to cause strong atmospheric instability that leads to thunderstorms with intense precipitation and stable isotope fractionation (the uplift height is set after modern observations; Altaratz et al., 2001; Galvin et al., 2011; Ben Ami et al., 2015). Next, the partially rained-out airflow undergoes dry adiabatic descent back to sea level at $\sim 10^{\circ} \mathrm{C} / \mathrm{km}$, and thereafter flows across the Levantine Sea at mean (') velocity $V_{H^{\prime}}=\left(V+V / s_{H}\right) / 2$. Here, $s_{H}$ (in the code, spacH where $H$ stands for Haifa) is a tuning factor that spreads the airflow over a larger spatial domain in the Levant so that simulated rainfall amounts for a control year approximate observed values, for eastern Levantine air uplift heights that are constrained by modern observations ( $\sim 6500 \mathrm{~m}$ for the Cyprus Low; Ganot et al., 2007). In both regions, modern annual precipitation values are about $500 \mathrm{~mm}$ (Climatemps.crete; Climatemps.haifa). Deep convection (thunderstorms) associated with the Cyprus Low is the main mechanism for strong precipitation in the region (Tarolli et al., 2012). This strong uplift again causes intense precipitation and stable isotope fractionation. Use of the tuning value $s_{H}$ in $V_{H^{\prime}}$ ensures conservation of mass in the airflow; $s_{H}$ is set once for a control year and then kept constant throughout.

The model also allows a measure of air uplift at times outside the cold events, which is set empirically using a sinusoidal function, between a winter maximum of $1220 \mathrm{~m}$ and a summer minimum of $0 \mathrm{~m}$. The winter maximum value represents a fine-tuning factor that empirically sets rainfall over Crete in a control year to observed values (Climatemps.crete). The summer-time zero value represents a crude approximation of summer-convection inhibition by mid-tropospheric descent (Tyrlis et al., 2013 and references therein). These, and a number of other parameterisations in the model setup, are rather subjectively selected within reasonable ranges, but they are warranted because our objectives are not about modelling reality. Instead, we tune settings to modern observed values for control years, and then only consider what relative changes would take place during anomalous years with an otherwise identical model setup.

After entering the study region, the air in the model flows out over a mixed layer of seawater of constant thickness (set to $100 \mathrm{~m}$ ), with an initial sea-surface temperature (SST) that varies through the year with a sinusoidal function between fixed seasonal extremes of 13 and $23^{\circ} \mathrm{C}$ (Rohling et al., 2002b and references therein), and with initial 
seawater salinity (SSS) of 39 and $\delta^{18} 0\left(\delta_{s}\right)$ of $1.5 \%$. Air-sea interactions change all three properties through time in the model. After a model year, these properties are reset to their initial values, in an approximation of the influence of large-scale spatial mixing/advection. If a degree of "memory" of the preceding year's changes were included, then the amplitude of simulated changes would be enhanced, so our simulated amplitudes should be considered as minimum estimates. The passage-time of air over the sea is calculated using wind speeds in combination with a scale factor for the N-S distance over the Aegean Sea and the ESE distance from Crete to Israel over the eastern Levantine Sea. We use $\sim 1400 \mathrm{~km}$ for the total distance from the north Aegean to the Israeli coast near Haifa, and simply consider that Crete splits this into two equal halves. For both landfall locations (Crete and Israel/Haifa), air temperatures at sea level are set using sinusoidal annual cycles between observed seasonal extremes (Climatemps.crete; Climatemps.haifa; Climatedata). The amplitudes of temperature anomalies during superimposed 10-day events at both Crete and Israel/Haifa are set equal to those in the initial airmass that enters the study region.

The model simultaneously resolves changes in SST, sea-surface salinity (SSS), evaporation and the stable oxygen isotope ratio of evaporation $\left(E, \delta_{e}\right)$, the timedependent development of the moisture content of air and its stable oxygen isotope composition ( $\delta_{a}$; including Rayleigh distillation when precipitation occurs), precipitation and its stable isotope ratio $\left(P, \delta_{p}\right.$, also considering Rayleigh distillation), net freshwater fluxes at sea level $(E+P)$, snowline $\left(0^{\circ} \mathrm{C}\right)$ altitude, negative degree-days at a set altitude (chosen at $2000 \mathrm{~m}$ to gauge longer-term snow preservation potential on the high mountains), and lake-level changes for hydrological changes at sea level at two hypothetical lake sites (one in Crete and one in Israel) as well as a Dead-Sea-like basin (see section 3.2).

$E$ and $\delta_{e}$ are calculated as outlined in Rohling (1999) and Rohling et al. (2004), except that the ratio of resistance coefficients is not set at 1.0142 in the $\delta_{e}$ calculation (Gonfiantini, 1986), but at a lower value of 1.010 (others have similarly used a lower value: Merlivat and Jouzel, 1979; Gat, 1996); thus, annual mean $\delta_{p}$ in both Crete and Israel in a control year is close to $-6 \%$, in approximate agreement with observations (Rozanski et al., 1993; Argiriou and Lykoutis, 2005; Dirican et al., 2005; Gat et al., 2005; Dotsika et al., 2010). $P$ is determined based on the local surface temperature and upliftrelated air temperature, pressure, and density changes and their impacts on saturation vapour pressure; for any given airflow with a certain moisture load, these changes cause relative humidity to increase as uplift occurs, until relative humidity reaches 1 , at which time precipitation occurs so that relative humidity is kept at 1 (it does not exceed saturation). The value of $\delta_{p}$ is calculated from the air-vapour ratio $\left(\delta_{a}\right)$ using condensation-temperature-dependent equilibrium fractionation (Majoube, 1971), combined with co-evolution of $\delta_{p}$ and $\delta_{a}$ due to Rayleigh distillation when precipitation occurs. After dry adiabatic descent back to sea level following the uplift over Crete, the air flow with its remaining moisture (and end-member $\delta_{a}$ ) flows over the eastern Levantine Sea, where it again gains moisture due to $E$ (and $\delta_{e}$ ), until uplift and cooling over the Levant, where $P$ and $\delta_{p}$ are calculated in the same manner as outlined before for Crete. For full details and further references, see the code provided.

Model performance for various ranges of event temperature and wind speed is evaluated in Figure 2. This provides basic set-up values for these parameters, which are 
evaluated for realism relative to observations, and which are then kept constant through all runs. That is, only the frequency of events is changed thereafter.

The above provides a single, physically coherent framework for calculating - for years with $0,1,3$, or 5 cold outbreak events per winter - the SST and SSS changes in the ocean mixed layer, as well as winter, summer, and annual mean values for $E$ and $P$ in Crete and Israel, with attendant $\delta_{p}$ values (and the size of the amount effect). In addition, the calculations give snowline altitudes in Crete and in the Levant, and negative degreedays at $2 \mathrm{~km}$ altitude in the mountains. These all become input parameters in our next exercise: to create a Holocene time-series of climate impacts using the GISP2 nssK ${ }^{+}$ time-series as a template for frequency changes of cold NPC air outbreaks (Rohling et al., 2002b).

\subsection{Generating time-series of Holocene variability}

To generate the Holocene time-series, the model divides the raw 3-year-resolution GISP2 nssK ${ }^{+}$time-series (Mayewski et al., 1997; Rohling et al., 2003) into classes, where $<50,50-80,80-95$, and $>95$ percentile values were related to years with $0,1,3$, or 5 events per winter, respectively (Figure 3a). This year-type record was then used to make a time-series of characteristics as modelled for each year-type. We then smoothed these resultant 3-year-resolution time-series of modelled parameters as appropriate for the temporal resolution of each type of proxy record in palaeoclimate studies that is equivalent to one of our modelled parameters. Mostly, we use 50-y Gaussian smoothing to highlight major patterns of change. However, simulated records of Aegean SST (and SSS) change were smoothed with a 200-y Gaussian window, to match marine proxy records (Figure 3c,d). The model primarily determines lake-level variations at the original output resolution because these are cumulative signals over time, and then smooths the resultant cumulative records with a 50-y Gaussian window (Figure 3g).

We also calculate first-order approximations for changes in cave-water and cavecarbonate oxygen isotope ratios, using $\delta_{p}$ and $\delta_{c}$, where the latter accounts for the water-carbonate fractionation effect of mean temperature changes (Figure 3h,i). These records are presented for the Levant based on the property simulations for Israel/Haifa, and were smoothed with a 20-y Gaussian window to visually compare the calculated variability with that observed in records from Jeita Cave in Lebanon (Cheng et al., 2015) (Figure 4a).

The idealised lakes resolved within the model each have a variable lake area within a constant catchment area, which are proportionally related as $1:\left(\Phi_{(t)}-1\right)$, where $\Phi_{(t)}=\left(A_{\text {catchment }}+A_{\text {lake }(0)}\right) / A_{\text {lake }(t)}$. Here, the base value of $\Phi$ (i.e., $\left.\Phi_{(0)}\right)$ is set in such a way that the lake is at steady state (zero change) for the climate parameters of the presentday "control" year (a 1-event year). We simply assume that all $P$ onto the catchment area immediately enters the lake without evaporative loss; thus, evaporative loss occurs only from the lake surface area itself. In essence, the modelled lakes occupy perfectly conical depressions, where the catchment area is represented by the maximum opening of the cone minus the time-dependent area of the lake within the conical depression. We specify for each lake a standard depth of $30 \mathrm{~m}$ for the present day, and set the slope of the conical depressions to 1 degree. Changes in the lake-slope angle strongly affect the initial lake area-and via $\Phi_{(0)}$ also the catchment area-but simulated lake-level 
variations are not significantly affected. The calculated past lake-level-changes are shown relative to the model's simulated present-day lake-level value.

Finally, we calculate lake-level variations for a Dead Sea-like basin, using a simplified version of the basin's area-to-depth ratio after Rohling (2013) (for details, see the code provided) and $\Phi_{D S(0)}=40$ after the same study (Figures 3g,4c). Further simplified representations after Rohling (2013) that are applied in the current model's Dead Sealike case are: $(a)$ a high-salinity-driven $\sim 50 \%$ reduction in the rate of evaporation from the basin, relative to evaporation from pure fresh water; and $(b)$ a value of $\sim 3$ for the ratio $P: P_{\text {preserved, }}$ where $P$ preserved stands for the amount of $P$ from the wider catchment area that makes it into the lake following loss through evapotranspiration (for details, see code provided). The model simulates a record of climate-imposed changes in the level of water within a Dead Sea-like basin, which then is normalised to $0 \mathrm{~m}$ for the present-day level.

There are some important caveats. First, as mentioned before, the model does not account for underlying astronomically forced variations in the region, given that the GISP2 $\mathrm{nssK}^{+}$Holocene record (used as input for our model) is dominated by variations at centennial to millennial timescales (O'Brien et al., 1995; Mayewski et al., 2004; Muschitiello et al., 2013). Second, all simulated records show variability related to only the wintertime RCC component considered, and ignore other influences resulting from, for example, summer droughts, and/or westerly or (south-)easterly air flows. Consequently, perfect representation of observed palaeoclimate proxy records and of their full centennial- to millennial-scale climate variability cannot be expected. Finally, we emphasise that the model output is especially focussed on comparison with records close to the simulated regions of precipitation, evaporation, and frost and snow potential (notably Crete and Levantine coastal to mountainous regions).

\section{RESULTS}

The modelled apparent interannual isotopic "amount effect" is determined similarly to how it affects stable oxygen isotopes recorded in a cave, namely in terms of the ratio between annual mean change in $\delta_{p}$ over annual mean change in $P$, between different years. We determine the amount effect as the mean of the two values of $\Delta \delta_{p} / \Delta P$ for a three-event year relative to a "control" year, and a five-event year relative to a "control year". Values are expressed as stable oxygen isotope difference per $100 \mathrm{~mm}$ of rainfall.

Our results identify the magnitude of cooling during each 10-day cold event as the most important control on the apparent interannual isotopic "amount effect" for Israel (Figure 2a, filled dots). This is not so much because of fractionation and Rayleigh distillation, but mainly because the magnitude of cooling has strong influences on both the amount of moisture held in the incoming air (lower for colder events), and the amount of evaporation from the sea (greater for colder events). The importance of this complex and somewhat counter-intuitive mixing-in shifting proportionalitiesbetween advected (external) and evaporated (Mediterranean) moisture casts doubt over qualitative assumptions about how changes in rainfall isotope compositions extrapolate across the wider region. Significant non-linearities in these relationships should be expected, so that quantitative evaluations are essential for good reconstructions. 
We identify the most representative initial cooling intensity for all events by comparison of the model's apparent interannual isotopic amount effect with that observed in Israel (Figure 2a, filled dots). Observations for Soreq Cave, Israel, imply a value of about $-0.5 \%$ per $100 \mathrm{~mm}$ of rainfall (Bar-Matthews et al., 2003). This is best approximated (within uncertainties) by the model for mean air-cooling during cold events of $\sim 9{ }^{\circ} \mathrm{C}$ (Figure 2a, heavy dashed arrow). For that value, there is also a good agreement with the individual $P$ amounts (open diamonds) and $\delta_{p}$ values (crosses) for both Crete and Haifa (Figure 2a). Accordingly, we set our main experiment to run with cooling amplitudes of $9{ }^{\circ} \mathrm{C}$ for each of the 10-day cold events. For the Cretan site, we simulate only a minor amount effect $(0.14 \%$ per $100 \mathrm{~mm}$ of rainfall), which agrees with an apparent lack of correlation between $\delta_{p}$ and $P$ reported for that location by Argiriou and Lykoutis (2005). That observation in Crete by itself indicates already that the classic interpretation of the apparent "amount effect" in the Levant may be questionable, because a similar, or at least systematically other, amount effect would then be expected in relatively nearby locations like Crete. The fact that our model finds coherence of simulated and observed differences between Crete and the Levant suggests that it offers a more realistic explanation of the apparent amount effect. Hence, as stated above, straightforward interpretations of regional $\delta_{p}$ changes in terms of $P$ changes through fractionation and Rayleigh distillation should be considered with significant caution; instead, changes in the balance between advective and evaporative moisture fluxes may be dominant.

Because evaporation rates are linearly related to mean wind speed, we assess the impacts of wind-speed changes as well (Figure $2 \mathrm{~b}$ ). We find that the impacts of windspeed changes on most parameters cancel out over the sea because travel time along the trajectories is inversely proportional to mean wind speed. Yet mean wind speed still affects annual cooling of the marine mixed layer. Long-term RCC expressions in the basin suggest cooling of $\sim 2{ }^{\circ} \mathrm{C}$, up to $3^{\circ} \mathrm{C}$ (see above). Such values are suggested by the model's 200-year-smoothed annual SST anomalies when the wind-speed anomaly during cold events $(V)$ is set to about $+10 \mathrm{~m} \mathrm{~s}^{-1}$ (Figure $2 \mathrm{~b}$ ). This value agrees with the aforementioned observations of northerly outbreak velocities from 17 to $25 \mathrm{~m} \mathrm{~s}^{-1}$, which imply anomalies of at least $10 \mathrm{~m} \mathrm{~s}^{-1}$.

Modern observations, highlighted before, corroborate our inferred mean cooling amplitudes of the order of $9^{\circ} \mathrm{C}$ (see code provided for various diagnostics from our main scenario). During cold NPC air outbreaks, cooling by $\geq 4^{\circ} \mathrm{C}$ occurred in Bulgaria and in the Alps, and observations in central Greece go as low as $-20^{\circ} \mathrm{C}$. In addition, observations of enhanced preservation of snow on Cretan mountains (which reach up to $2500 \mathrm{~m}$ ) agree with strong negative-degree-days amplitudes calculated for high Cretan altitudes (Figure 3b). With mean cooling amplitudes of the order of $9^{\circ} \mathrm{C}$, the model also suggests snow-line drops to altitudes of 770 and $920 \mathrm{~m}$ for the Levant and Crete, respectively, which are coherent with snow events observed in Jerusalem $787 \mathrm{~m}$; see also below). In addition, modern observations during cold events report deep frosts (and snow) at low altitudes in the northern Aegean (e.g., Thessaloniki) and Bosporus regions, in agreement with the model's event-mean minimum temperatures down to $8^{\circ} \mathrm{C}$ in regions north of the Aegean. This is consistent also with air temperatures in 2001, which were still as low as 0 to $-2^{\circ} \mathrm{C}$ after passing a considerable distance over the relatively warm northern Aegean Sea (Casford et al., 2003). Within each event, there 
may be colder spikes, but these are not resolved; our model's $9^{\circ} \mathrm{C}$ cooling anomaly represents the mean for an entire 10-day event.

The modelled amplitudes of precipitation change also help in validating the model's performance. For both Crete and Israel (Haifa), the model returns values of $505 \mathrm{~mm} \mathrm{y}^{-1}$ for the present control year (unsurprisingly, given that the model's settings are tuned to these control-year values). In a year with 5 cold events, the model infers an annual $P$ amount of $798 \mathrm{~mm}$ for Crete and $777 \mathrm{~mm}$ for Israel. Five cold events in the model amount to 50 days, which is 40 more than in a control year with one 10-day event. For both locations, that implies roughly $7 \mathrm{~mm}$ of extra rain per day, assuming that it rains all day, every day, and that all rain is spatially equally distributed. In reality, there is inhomogeneity, with locally and temporally intensified bursts of rain that alternate with dry/drier spells. Even over relatively small distances, spatial focusing (e.g., orographic effects) imparts factor-3 differences between high and low rainfall values (Shamir et al., 2016). Over larger distances, such contrasts are likely to be stronger. And temporal focussing also occurs, where some regions stay dry while others receive most of the rainfall. If we tentatively allow for a reasonable range of $3 \times$ to $10 \times$ combined spatial and temporal focussing of $P$ during the events, then local peak daily rainfall values of $\sim 20$ to $\sim 70 \mathrm{~mm}$ might be anticipated from the model results, which we compare below with modern reported extreme rainfall events.

On 13 December 2016, heavy downpours hit Israel, with rainfalls up to $10 \mathrm{~mm}$ (Timesofisrael). On 25 November 2014, more than $40 \mathrm{~mm}$ of rain fell on many regions from North to South through Israel (Israelnationalnews), while a persistent storm in the earliest days of November 2015 brought rainfalls between 80 and $150 \mathrm{~mm}$ over 7 days (daily averages of $\sim 11$ to $\sim 21 \mathrm{~mm}$ ) (Israelnationalnews). Unusually heavy rainfall of up to $50 \mathrm{~mm}$ fell within a day at many places in Israel on 10-11 December 2013, accompanied by northerly winds and unseasonably cold conditions (Floodlist). Such storms are often associated with snow, especially on the higher mountains (e.g., Mount Hermon in the north, $\sim 2800 \mathrm{~m}$ high), but also extending much lower (e.g., up to $15 \mathrm{~cm}$ in Jerusalem at $787 \mathrm{~m}$ altitude, in January 2013; Dailymail). In view of these reports, our simple model does a reasonable job at approximating the scale of $P$ increases associated with the cold events. The weather reports also validate our simulated event-average drops in snowline-altitudes, down to the altitude of Jerusalem.

With respect to lakes, the model investigates identical idealised lake shapes at sea level in both Crete and Israel. In both cases, the assumed initial lake depth of $30 \mathrm{~m}$ and lakeside slope of 1 degree geometrically determine the initial lake diameter (3437 $\mathrm{m}$ ) and lake surface area $\left(9.28 \times 10^{6} \mathrm{~m}^{2}\right)$. The size of each lake's catchment area is found via region-specific multiplier $\Phi_{(0)}$. For the calculated control-year conditions, $\Phi_{(0)}=2.27$ for Crete, and $\Phi_{(0)}=1.92$ for Israel, giving total (catchment+lake) areas of $2.11 \times 10^{7} \mathrm{~m}^{2}$ and $1.78 \times 10^{7} \mathrm{~m}^{2}$, respectively (see code for details). Once determined for the present control year, these total areas are kept constant throughout the model runs because the total catchment area in nature relates to a topography that is invariant on the short timescales considered here. The proportion of the total area that is made up by the lake itself fluctuates with lake-level changes, which relate to each year's simulated hydrological conditions. By specifying exactly the same lake shape for both regions, and setting both up so that they are at steady state in a control year, we can directly 
compare and contrast the lake-level responses to regionally different consequences of a single set of imposed climatic perturbations.

The lake-level simulations (Figure 3g) show that, as a rule of thumb, periods with no/fewer cold events result in lake-level drops, and periods with more cold events result in lake-level rises. Lake-level minima and maxima, respectively, follow such episodes with lags of a few decades for lakes of the dimensions used here. This is because lake levels represent an integrated signal of preceding non-steady-state conditions in the catchment's E-P balance (i.e., the underpinning connection is between prevailing climate conditions and the rate of lake-level change). Within uncertainties, the specified systems respond very similarly in Israel and Crete (Figure $3 \mathrm{~g}$ red, blue). But we emphasise that real-world examples require careful definition of the timevariable lake-surface-area occupation of part of the total surface area $\left(\Phi_{(t)}\right)$. This requires use of detailed digital elevation models and lake-level and drainage assessment, since $\Phi_{(t)}$ is a critical term for case-specific lake-level responses (see also Rohling, 2016).

The simulated level variations in the model's Dead Sea-like basin (Figure 3g, green) are similar to those of those in the two idealised lakes, but with larger amplitudes that are specifically characterised by proportionally stronger lake-level drops. These differences arise predominantly from the much larger ratio of catchment area to lake area $(\Phi)$ in the Dead Sea-like case, and from the high $P: P_{\text {preserved }}$ ratio applied to the basin which considerably increases the $E: P$ balance.

Simulated fluctuations in $\delta_{p}$ are of similar sign for Crete and Israel, but their amplitudes are very different (Figure $3 \mathrm{f}$ ). Conversely, the simulated amplitudes of $P$ changes are similar between Crete and Israel. This implies that the amount-effect ratio of $\delta_{p}: P$ varies considerably between sites (see above).

\section{DISCUSSION}

The simulated Holocene climate variability, using GISP2 nssK+-based variations in event frequencies, reveals a pattern that consists of a relative flat "background" with distinct multi-decadal to centennial-scale anomalies (Figure 3). This pattern, without long-term orbital modulation, arises from the approach followed (section 3), which is not designed to capture orbital-scale changes, but focuses on RCC anomalies only. Accordingly, the output of our model can only be used to compare climate anomalies during the RCCs with times in between the RCCs. The simulated time-series capture to a remarkable degree the multi-centennial variability seen in time-series of proxy climate data for the region, and specifically that in SST records (e.g., Abu-Zied et al., 2008; Clarke et al., 2016; Gogou et al., 2016; Kuhnt et al., 2007; Marino et al., 2009; Rohling et al., 2002a,b) (Figures 3c, 5). This implies that the fundamental nature of the observed temperature records is well represented by the model, and that the RCC mechanism of northerly air outbreaks is a key driver of interannual to multi-centennial Aegean SST variability (as it still is today; e.g., Josey et al., 2011).

The model simulates both increased $P$ and decreased $\delta_{p}$ in Crete and Israel during periods with a higher frequency of cold northerly outbursts (Figure 3e,f). Decreases in $\delta_{p}$ are conventionally interpreted as periods with increased $P$. Because the sign of $\delta_{p}$ variations is the same for Crete and Israel, palaeoclimatic interpretations based on $\delta_{p}$ 
variations would therefore offer the same (qualitatively consistent; see Figure 3f) conclusion that RCC-like episodes with higher frequencies of cold events in the region coincided with increased $P$. This would apply at all locations where the cold (and thus initially relatively dry) airstream makes landfall after gaining moisture during a substantial transit over the evaporative Aegean and Levantine Seas. In quantitative terms, however, the amount of $P$ that corresponds to a given unit of change in $\delta_{p}$ differs strongly from site to site on regional scales (see contrast between Crete (blue) and Israel (red) in Figure 3f). Hence, it appears that $\delta_{p}$ is not a good tool for straightforward mapping of patterns of $P$; physically coherent, quantitative assessment (modelling) is essential to such exercises.

There is some qualitative support from palaeoclimatic reconstructions for the model's expected regional $P$ increases during RCC events. Certain RCCs (especially that at around $8 \mathrm{ka}$, but also the LIA) bear evidence of intervals of sharply increased precipitation/runoff, including rubble/mud slides and flash-flood deposits (e.g., Xoplaki et al., 2001; Bar-Matthews et al., 2003; Peyron et al., 2011; Lespez et al., 2013; Berger et al., 2014). Boyer et al. (2006) reported a flooding phase on the Konya plain, Anatolia, with a calibrated radiocarbon date in the range of 8.75-8.45 ka BP (extending to $\sim 9-8 \mathrm{ka}$ $\mathrm{BP}$ based on datings in another section). This was later interpreted by Roberts et al. (2016) in terms of enhanced spring snowmelt following cold winters with increased snow cover, along with less precipitation in other seasons.

In contrast, stable hydrogen isotope data (which behave comparably, albeit not identically, to stable oxygen isotopes in the hydrological cycle; Hoefs, 1997), measured on vegetation remains from northern Greece, suggest aridification at 8.7-8.2 ka BP, followed by a sharp reversal to surface wetness at 8.2-8.0 ka BP (the "8.2 ka" Hudson Bay flooding event) with a subsequent gradual increase in surface wetness until $7.5 \mathrm{ka}$ BP (end of the reported study) (Schemmel et al., 2016). Note, however, that the rainfall regime over northern Greece is not predictable using the system evaluated here, given that this regime does not strongly depend on winter-time passage of northerly airflows over the Aegean-Levantine Seas and subsequent uplift upon landfall, so we refrain from further discussing records from this sector of the Aegean region (Kotthoff et al., 2008; Pross et al., 2009; Schmiedl et al., 2010; Schemmel et al., 2016).

Besides SST, the most convincing and consistent corroboration for the model results comes from the very highly resolved and precisely dated cave-speleothem $\delta^{18} 0$ record from Jeita Cave, Lebanon (Cheng et al., 2015) (Figures 4a, 5). The relatively nearby record for Soreq Cave, Israel, is of generally lower and irregular resolution through the Holocene (Bar-Matthews et al., 2003; Bar-Matthews and Ayalon, 2011), so we focus on Jeita Cave. The Jeita Cave speleothem $\delta^{18} 0$ record was originally interpreted in terms of correlation to so-called Bond events in the North Atlantic, but a physical process link remained to be quantitatively demonstrated. Given that Bond events show a rough correlation with RCCs as determined from the GISP2 nssK ${ }^{+}$record (Mayewski et al., 2004), we here compare the output of our RCC model with the centennial-scale component of the Jeita Cave $\delta^{18} 0$ record. Specifically, we compare our temperaturecorrected speleothem carbonate $\delta^{18} 0$ approximation $\left(\delta_{c}\right)$ with a high-pass filtered record of Jeita Cave (Figure 4a), which highlights the short-term (sub-millennial) fluctuations and removes the underlying, long-term trend related to the general Holocene climate evolution of the Levant that is not accounted for in our model. The 
Jeita Cave $\delta^{18} 0$ residual record is highly dynamic on centennial and shorter timescales (Figures $4 \mathrm{a}, 5$ ). On the whole, on centennial scales, we observe a striking agreement between RCCs, our expected $\delta_{p}$ and $\delta_{c}$ trends for Israel (Figure 3f, red), and negative Jeita Cave anomalies $\delta^{18} 0$ (Figures $4 \mathrm{a}, 5$ ). Even the high-frequency variability in our simulated $\delta_{c}$ record shows remarkable similarity with the high-pass Jeita Cave $\delta^{18} 0$ residual record (Figure 4a).

These agreements indicate that our simple model's representation of a key climate mechanism in the study region not only simulates well-documented multi-centennial SST variability, but also provides a sound first-order quantitative understanding of centennial-scale (and shorter) $P, \delta_{p}$, and cave- $\delta_{c}$ variations in the Levant (Figures 3-5). Note that our simulated $\delta_{c}$ record for Israel (Figure $3 \mathrm{~h}$ ) by design only captures anomalies related to the winter-time RCC mechanism that is considered. Given that this fails to explain the positive Jeita Cave anomalies (Figure 4a, grey), we infer that the Middle East was affected by a second dominant climate mode in the region; possibly, droughts associated with (summer-time?) extension of evaporative subtropical conditions, which may also underpin, for example, the droughts documented in Iran during some RCCs (Sharifi et al., 2015).

Our calculations for lake-level variations in a Dead Sea-like basin present a systematic pattern of highstands during RCCs (Figure 4c). This conflicts with reconstructions for the actual Dead Sea, which show a more complex suite of responses (e.g., Migowski et al., 2006; Torfstein et al., 2013a,b) (Figures 4c). Unfortunately, however, some of these reconstructions show a major peak at around 6.0 ka BP (Torfstein et al., 2013a,b; Kagan et al., 2015), while this is conspicuously absent from other reconstructions (Migowski et al., 2006; Litt et al., 2012). We have failed to find an in-depth debate and consensus on this issue (cf., Zielhofer and Weninger, 2013; Stein and Litt, 2013). Once a consensus Dead Sea reconstruction emerges, we propose that the difference between this record and our hypothetical simulation might be used to evaluate climatic impacts on the real basin that are overlooked in our model, similar to our assessment of the positive Jeita Cave anomalies.

Finally, we summarise recent syntheses of climate events around the study region in Figure 5. Within the RCC bands, and especially the tighter intervals of the regional eastern Mediterranean RCC expressions (Rohling et al., 2002b), arid signatures seem to be rarely reported. When they are, such arid signals are mostly seen in: (a) the North Aegean sector, at the upstream side of our northerly airflow mechanism, for the RCC of 8.6-8.0 ka BP (though it changes to a wetter expression from $8.2 \mathrm{ka}$ BP; Schemmel et al., 2017); (b) several intervals around the region within the RCC of 6-5 ka BP (in the Holocene climate compilation of Clarke et al. (2016) that includes the data from Roberts et al. (2011)); and (c) several RCCs in high-altitude Anatolia (Figure 5). Most other reported relatively arid intervals fall outside the RCCs.

It is difficult to perceive a systematic pattern from such a scattering of information (Figure 5), especially because different proxies have been interpreted in different ways, and because age models are not always very precise. In contrast, the agreement between our model output and the Jeita Cave record of Cheng et al. (2015) convincingly argues that more humid conditions reached from the northwest into the Levant during the RCC intervals, as discussed above. In short, our synthesis implies that most arid 
events reported from locations downstream of the cold NPC mechanism fall in between the RCCs, and that RCCs in such locations were the more humid intervals.

The aforementioned indications (Figure 5) that climatic signatures on the Anatolian highlands may have been roughly opposite to those in the (lower altitude) rest of the study region may be of regional climatological significance. We propose that highaltitude Anatolian conditions were more directly related to the initial continental conditions found to the north of the Aegean Sea, than to those in the low-altitude atmospheric mixed layer over the Aegean/Levantine Sea where marine evaporation plays a key role. This would be supported by extensions of intensely cold Eurasian continental air masses over the Anatolian highlands during severe winter cold snaps of recent years (e.g., Coulter, 2012).

\section{CONCLUSIONS}

We present a simple 2-dimensional Lagrangian model to evaluate the nature of climate variability in the Aegean/Levantine region during the Holocene RCCs, with implications for major archaeological turn-over events in the region. Our model simulates the impacts of frequency changes in winter-time northerly air outbreaks over the study region (the "RCC mechanism") on key climate parameters, such as: sea-surface temperature and salinity, evaporation and stable oxygen isotope ratio of evaporation; time-dependent development of the moisture content of air and its stable oxygen isotope composition; precipitation and its stable isotope ratio, net freshwater fluxes at sea level; snowline altitude; negative degree-days at 2,000 $\mathrm{m}$ to gauge longer-term snow preservation potential on the high mountains; and lake-level changes for hydrological changes at sea level in both hypothetical lakes and a Dead-Sea-like basin.

Our model corroborates the notion that RCCs were regionally cold intervals (notably, cold winters) and indicates that the predominant climatic impacts of this winter-time mechanism were "cold and wet," in contrast with intercalated non-RCC "warm and arid" conditions, in the regions downstream of the Aegean and Levantine Seas. To be more specific and precise, the RCCs were periods of highly variable conditions, with an overall tendency toward cold and wet conditions with potential for flash flooding and for episodic snow-cover at low altitudes, at least in the lower-altitude (lower 1 to $1.5 \mathrm{~km}$ ) regions of Crete and the Levant. The warm and arid intervals in between RCCs require further investigation; we tentatively propose that another mode of climate variability in the region may involve (summer-time?) extension of evaporative subtropical conditions.

Our results also imply that the "amount effect" observed in Levantine cave $\delta^{18} 0$ (and precipitation or drip-water $\delta^{18} 0$ ) does not reflect the conventional concept related to temperature-dependent fractionation and Rayleigh distillation. Instead, it arises because the magnitude of cooling changes the mass-balanced mixing between the amount of moisture held in the incoming air (lower for colder events), and the amount of moisture added due to evaporation from the sea (greater for colder events). The importance of this complex and somewhat counter-intuitive mixing-in shifting proportionalities-between advected (external) and evaporated (Mediterranean) moisture casts doubt over qualitative assumptions concerning the spatial application of a certain "amount effect" through the study region. This is well-illustrated by modern 
976 observations of a negligible "amount effect" in Crete versus a distinct "amount effect" in 977 Israel. In short, fully quantified evaluations are essential for good reconstructions.

978

979 Finally, our results illustrate that apparent covariations between warm/cold and 980 arid/wet conditions for any given climate event should not be expected to apply over a 981 wide region, but instead are likely to differ spatially, and possibly also with altitude. Acknowledgements. This work was supported by Australian Laureate Fellowship FL120100050 (E.J.R.). G.M. acknowledges support from the University of Vigo

985 programme to attract excellent research talent, and a generous start-up package. Data and MATHCAD code are at http://www.highstand.org/erohling/ejrhome.htm. 


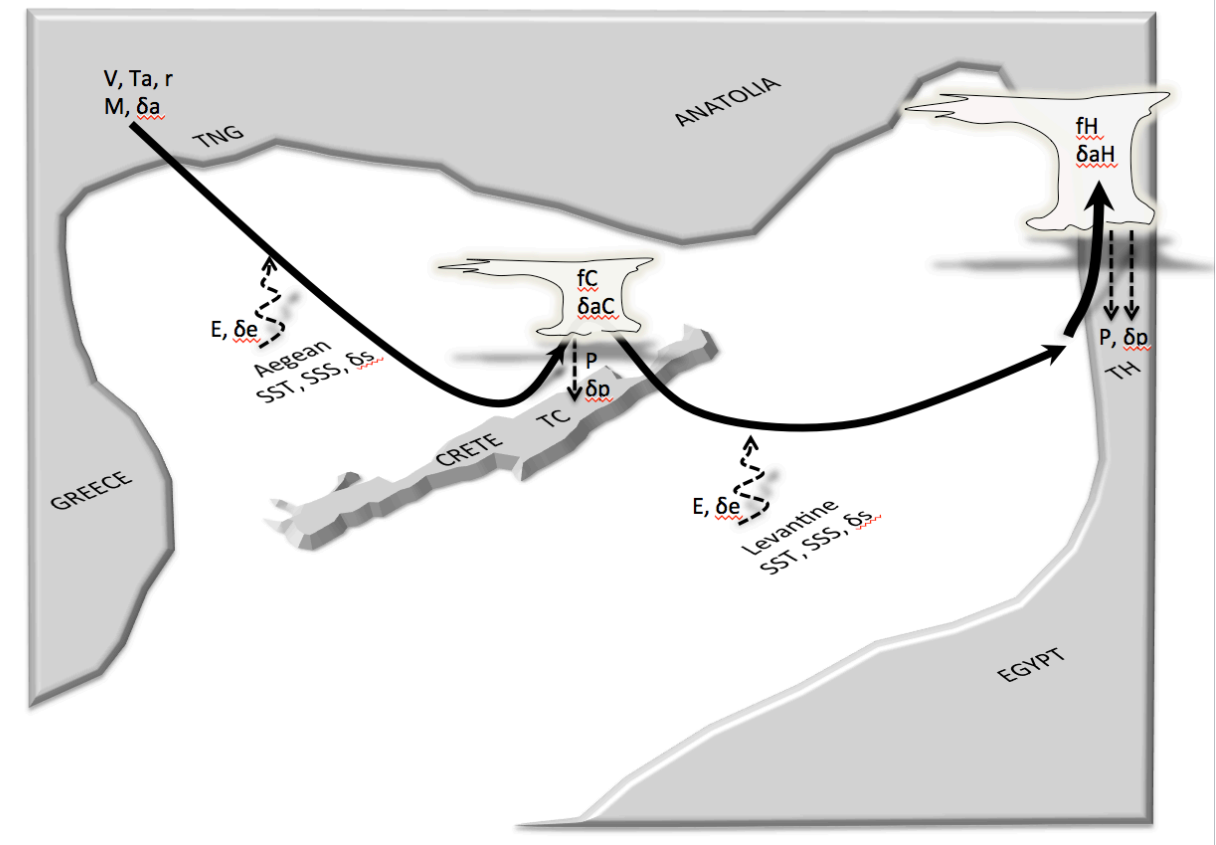

Figure 1. Sketch of the model. $V$ is wind speed. $T_{a}$ is air temperature, $r$ is relative humidity, $M$ is moisture/vapour mass, $\delta_{a}$ is the 0 -isotope composition of the vapour, $E$ is evaporation (in m per unit area), $\delta_{e}$ is the 0 -isotope composition of the vapour added by evaporation, $f_{C}$ is the fraction of remaining vapour after rainout over Crete, $\delta_{a C}$ is the 0 -isotope composition of the remaining vapour after rainout over Crete, $P$ is precipitation (in m per unit area), $\delta_{P}$ is the 0 -isotope composition of precipitation, $f_{H}$ is the fraction of remaining vapour after rainout over Haifa (Israel), $\delta_{a H}$ is the 0 -isotope composition of the remaining vapour after rainout over Haifa. SST is sea surface temperature, SSS is sea surface salinity, $\delta_{s}$ is the sea surface 0 -isotope composition, all in mean values for a mixed layer of $100 \mathrm{~m}$ thickness. $T_{N G}, T_{C}$ and $T_{H}$ are surface temperatures at northern Greece, Crete, and Haifa, respectively. 

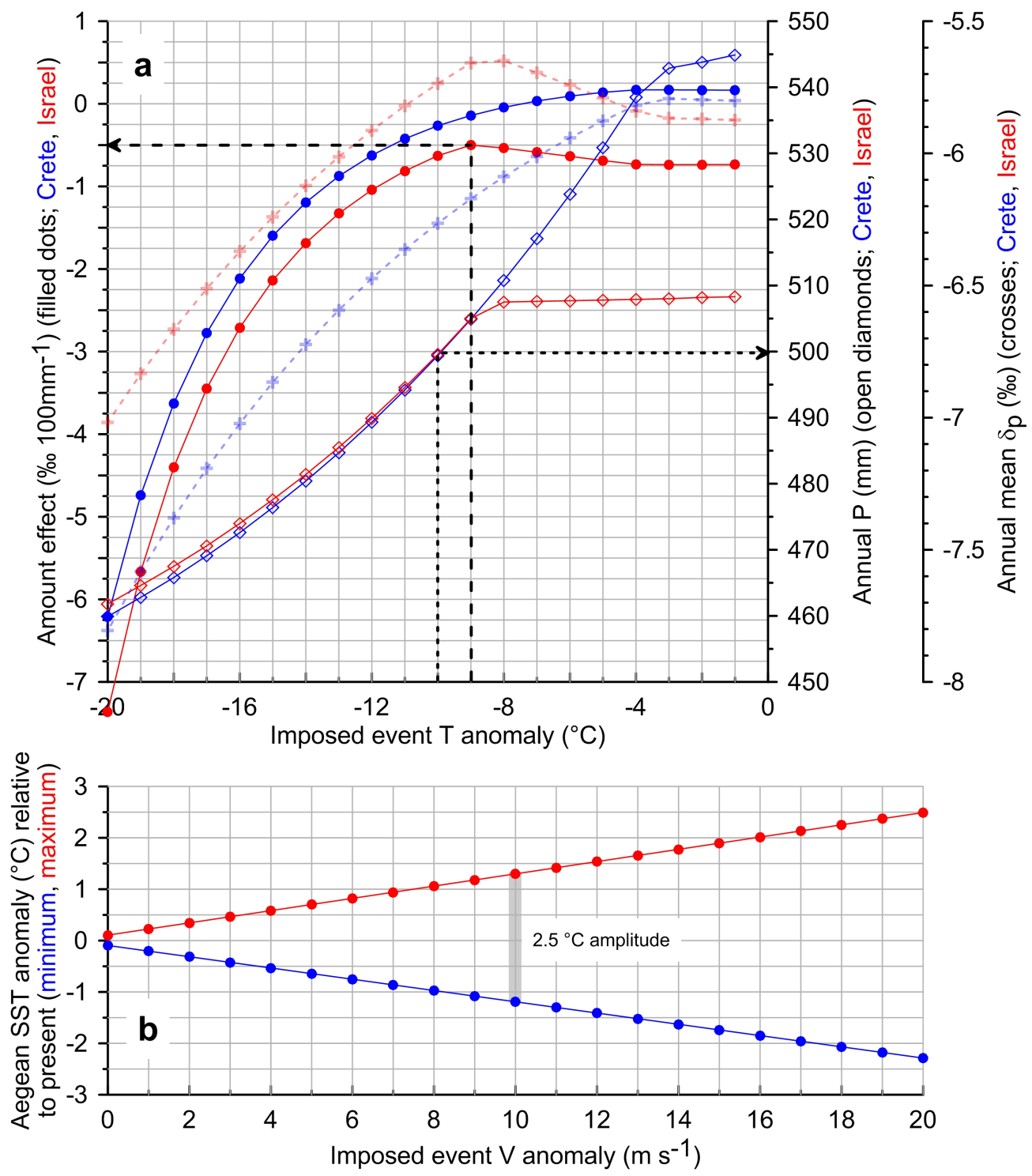

Figure 2. Model diagnostics. The main sensitivities are to the mean magnitude of cooling during the northerly cold air outbreak events, and to the wind speed anomalies during these events. (a) Dependence of several model parameters to the former; the model's emergent "amount effect" for precipitation/cave waters in Israel/the Levant is a strong diagnostic for setting the mean magnitude of cooling during the events. Arrows indicate the selected settings. (b) Dependence of Aegean sea-surface temperature on mean wind speed. The grey bar indicates the wind speed anomaly for which good agreement is reached between the modelled range of SST change and that in observations. 


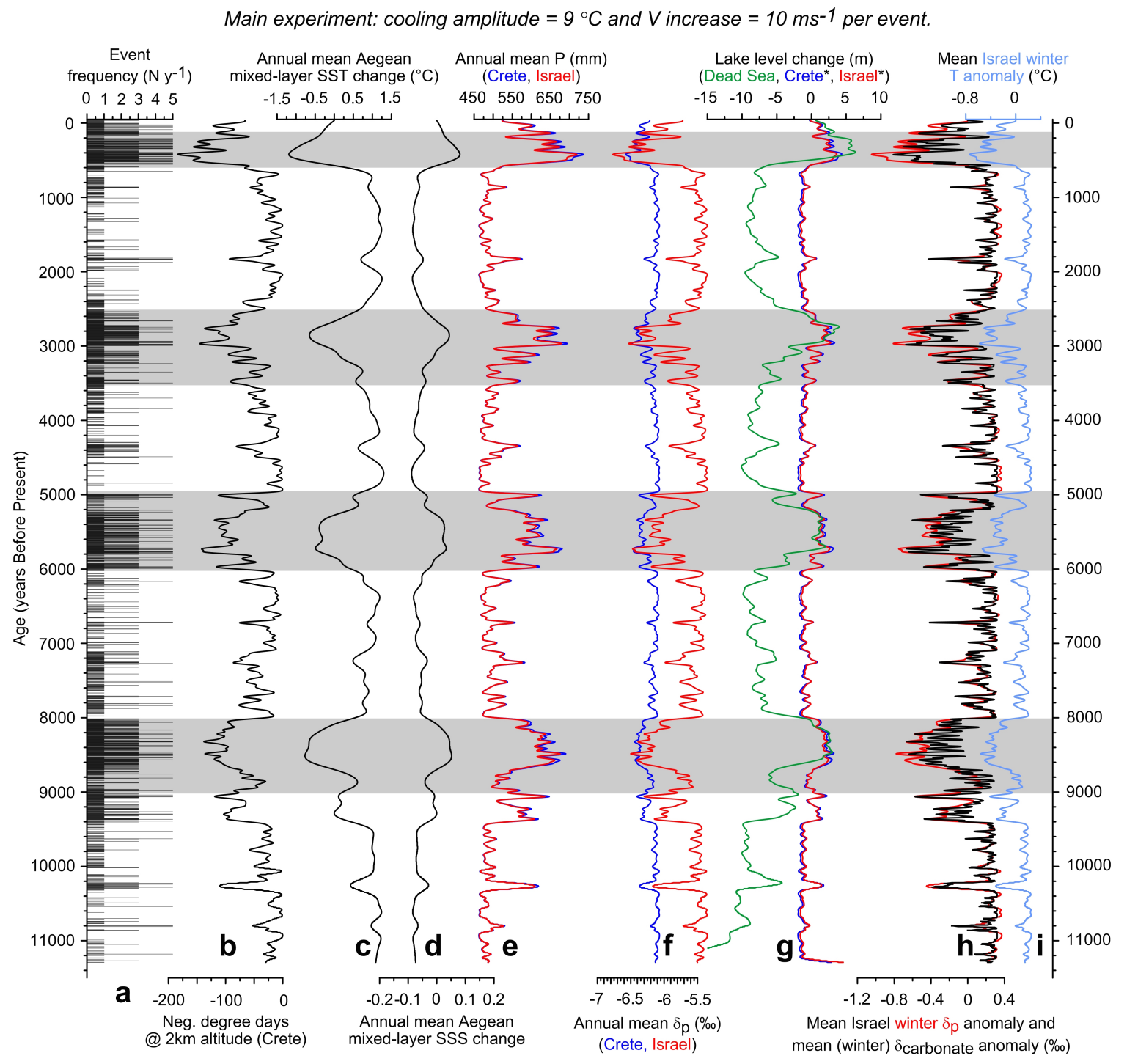

Figure 3. Time-series of results for the main model experiment. (a) Year type in terms of event frequency. (b) Negative degree days at $2 \mathrm{~km}$ altitude in Crete (more negative values indicate stronger snow/ice survival potential). (c) Aegean sea surface temperature. $(d)$ Aegean sea surface salinity. (e) Annual mean $P$ values for Crete (blue) and Israel (red). $(f)$ Annual mean $\delta_{P}$ for Crete (blue) and Israel (red). ( $g$ ) Lake level changes relative to the modern control value for hypothetical conical lakes in Crete (blue) and Israel (red), plus the simulated Dead-Sea-like basin (green). ( $h$ ) Mean Israel winter $\delta_{P}$ anomaly (red) relative to the modern control value, and the mean winter carbonate $\delta^{18} \mathrm{O}$ value for Israel (black), which are based on the $\delta_{P}$ anomalies and the mean winter temperature anomaly for Israel shown in (i). The temperature anomalies and thus carbonate $\delta^{18} 0$ anomalies are values calculated at $0 \mathrm{~m}$ (sea-level) altitude. See text for the different smoothing factors used for different records, to best approximate potential resolutions in records of palaeo or historical data. The grey bars outline the main RCCs after (Mayewski et al., 2004). 


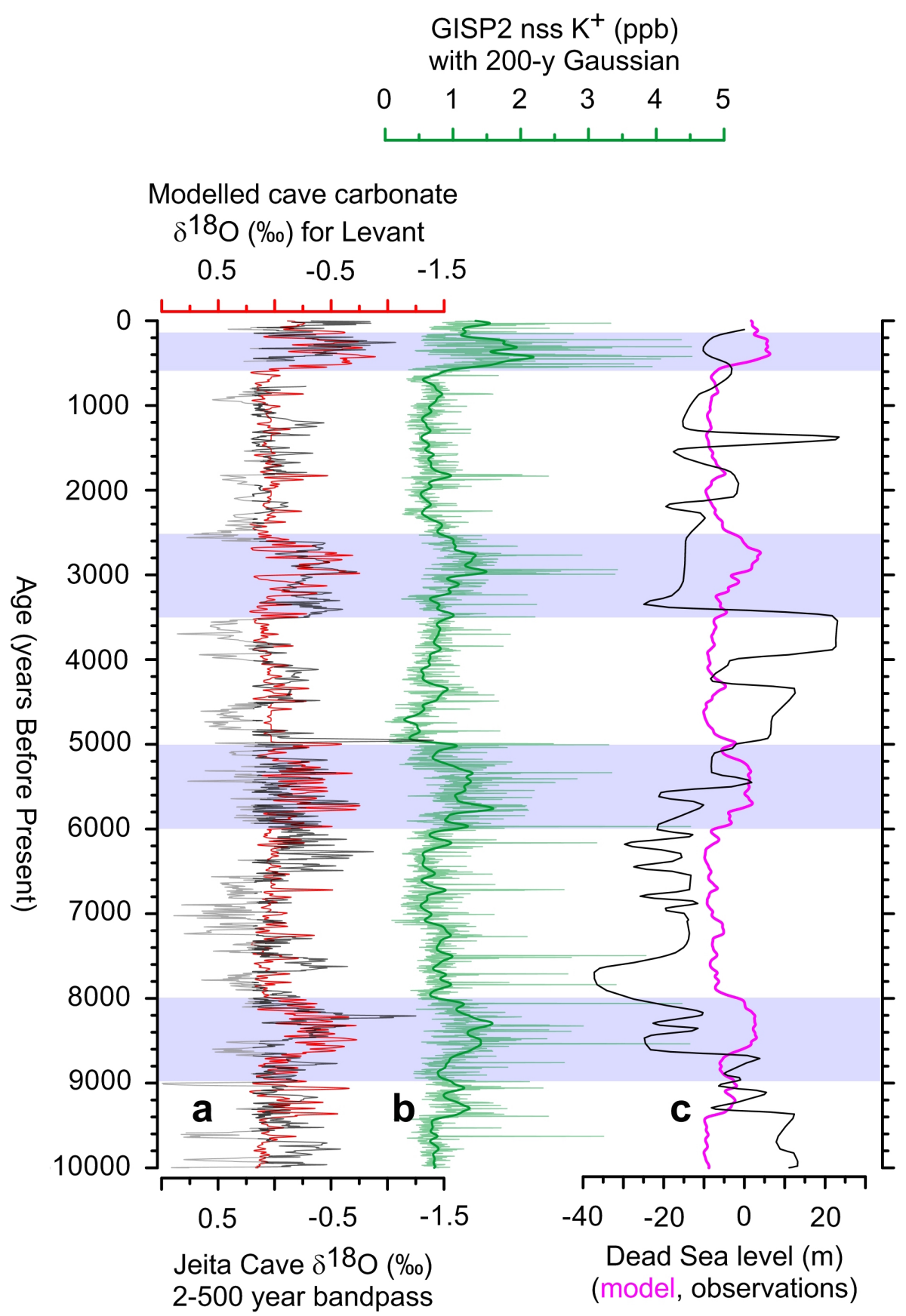

Figure 4. (a) Specific comparison of modelled cave-carbonate $\delta^{18} 0$ variations with the high-frequency (2-500 year bandpass) component of the Jeita Cave carbonate $\delta^{18} 0$ record from Lebanon (Cheng et al., 2015). In the Jeita Cave record, positive anomalies are shown in grey and negative anomalies in black. The modelled record was driven by the model's frequency of northerly outbreak events based on $(b)$ the raw GISP2 $\mathrm{K}^{+}$ record (green, with 200-y Gaussian smoothing to show main trends). (c) Comparison between the model-generated record for a Dead Sea-like basin (magenta), with caveats discussed in the main text, and (black) the Dead Sea observations of Migowski et al. (2006). 


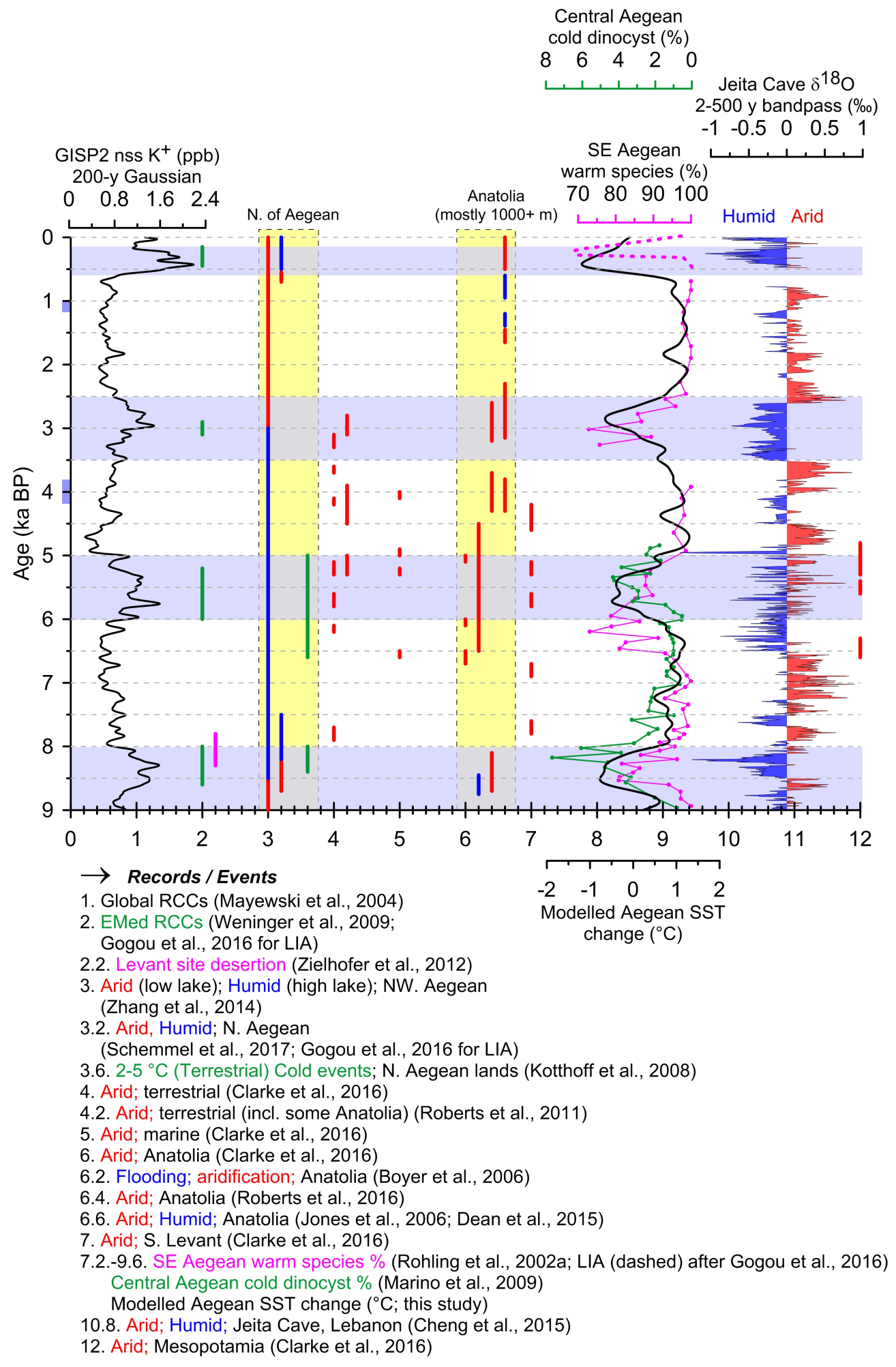

Figure 5. Comparison of signals as reported in the literature. Individual expressions in the study region are organised by numbered (x-axis) studies, organised roughly from the north to the south-southeast. The widespread Holocene RCCs described by Mayewski et al. (2004) are indicated with blue shading (small shaded blocks at about 4 and $1 \mathrm{ka} \mathrm{BP}$ indicated often-reported events that do not have clear expressions in the 
GISP2 nssK ${ }^{+}$record). On the right-hand side are the well-defined Aegean SST trends and the high-frequency component of variability in Jeita Cave $\delta^{18} 0$.

990 


\section{References}

992 Abu-Zied, R.H., Rohling, E.J., Jorissen, F.J., Fontanier, C., Casford, J.S.L., Cooke, S., 2008.

993 Benthic foraminiferal response to changes in bottom-water oxygenation and organic

994 carbon flux in the eastern Mediterranean during LGM to Recent times. Marine

995 Micropaleontology 67, 46-68.

996 Alley, R.B., Mayewski, P.A., Sowers, T., Stuiver, M., Taylor, K.C., Clark, P.U., 1997.

997 Holocene climatic instability: A prominent, widespread event 8200 yr ago. Geology 25,

998 483-486.

999 Alpert, P., Shafir, H., 1989. Mesog-Scale distribution of orographic precipitation:

1000

1001

1002

1003

1004

1005

1006

1007

1008

1009

1010

1011

1012

1013

1014

1015

1016

1017

1018

1019

1020

1021

1022

1023

1024

1025

1026

1027

1028

1029

numerical study and comparison with precipitation derived from radar measurements.

Journal of Applied Meteorology 28, 1105-1117.

Alpert, P., Neeman, B.U., and Shay-El, Y., 1990. Climatological analysis of Mediterranean cyclones using ECMWF data. Tellus 42A, 65-77.

Altaratz, O., Levin, Z., Yair, Y., 2001. Winter thunderstorms in israel: a study with

lightning location systems and weather radar. Monthly Weather Review 129, 12591266.

Ammermann, A.J., Cavalli-Sforza, L.L., 1979. The wave of advance model for the spread of early farming. In C.Renfrew and K.L.Cooke (eds), Transformations: Mathematical Approaches to Culture Change, pp. 275-294. New York. Academic Press.

Anagnostopoulou, C., Tolika, K., Lazoglou, G., Maheras, P., 2017. The exceptionally cold January of 2017 over the Balkan Peninsula: a climatological and synoptic analysis. Atmosphere 8, 252, doi:10.3390/atmos8120252.

Anderson, D.G., Maasch, K.A., and Sandweiss, D.H. (eds.), 2007. Climate Change and Cultural Dynamics. A Global Perspective on Mid-Holocene Transitions. Academic Press. Elsevier.

Argiriou, A.A. , Lykoutis, S.P., 2005. Stable isotopes in rainfall over Greece: results of the 2000-2003 measurement campaign. In: Isotopic composition of precipitation in the Mediterranean Basin in relation to air circulation patterns and climate-Final report of a coordinated research project 2000-2004. IAEA-TECDOC-1453, pp. 83-97, IAEA, Austria.

Asouti E., Fuller, D.Q., 2013. A Contextual Approach to the Emergence of Agriculture in Southwest Asia. Current Anthropology 54, 299-345.

Barber, D.C., Dyke, A., Hillaire-Marcel, C., Jennings, A.E., Andrews, J.T., Kerwin, M.W., Bilodeau, G., McNeely, R., Southon, J., Morehead, M.D., Gagnon, J.M., 1999. Forcing of the cold event of 8,200 years ago by catastrophic drainage of Laurentide lakes. Nature 400, 344-348.

Bar-Matthews, M., Ayalon, A., 2011. Mid-Holocene climate variations revealed by highresolution speleothem records from Soreq Cave, Israel and their correlation with cultural changes. Holocene 21, 163-171.

1030 Bar-Matthews, M., Ayalon, A., Gilmour, M., Matthews, A., Hawkesworth, C.J., 2003. Sea1031 land oxygen isotopic relationships from planktonic foraminifera and speleothems in the 1032 Eastern Mediterranean region and their implication for paleorainfall during interglacial 1033 intervals. Geochimica et Cosmochimica Acta 67, 3181-3199.

1034 Bar-Yosef, 0.,1986. The Walls of Jericho: An Alternative Interpretation. Current 1035 Anthropology 27, 157-162. 
Ben Ami, Y., Altaratz, O., Yair, Y., Koren, I., 2015. Lightning characteristics over the eastern coast of the Mediterranean during different synoptic systems. Natural Hazards and Earth System Science 15, 2449-2459.

Berger, J-F., Garyfalia, G., Guilaine, J., 2014. Vers une révision de la transition mésonéolithique sure le site de Sidari (Corfou, Grèce). Nouvelles données géoarcheologiques et radiocarbon, évaluation des processus pos-dépositionelles. In: Claire Manen, Thomas Perrin et Jean Guilaine (eds.), La Transition Néolithique en Méditerranée, Archives d'Écologie Préhistorique, Arles at Toulouse, pp. 209-228.

Biehl, P.F., Nieuwenhuyse, O.P. (eds.), 2016. Climate and Cultural Change in Prehistoric Europe and the Near East. Suny Series. The Institute for European and Mediterranean Archaeology Distinguished Monograph Series.

Borrell, F., Junno, A., Barceló, J.A., 2015. Synchronous Environmental and Cultural Change in the Emergence of Agricultural Economies 10,000 Years Ago in the Levant. PLoS ONE 10, doi:10.1371/journal.pone.0134810

Bosmans, J.H.C., Drijfhout, S.S., Tuenter, E., Hilgen, F.J., Lourens, L.J., Rohling, E.J., 2015. Precession and obliquity forcing of the freshwater budget over the Mediterranean. Quaternary Science Reviews 123, 16-30.

Boyer, P., Roberts, N., Baird, D., 2006. Holocene environment and settlement on the Çarşamba alluvial fan, south-central Turkey: integrating geoarchaeology and archaeological field survey. Geoarchaeology 21, 675-698.

Budja, M. 2007. The 8200 calBP 'climate event' and the process of neolithisation in south-eastern Europe. Documenta Praehistorica 34, 191-201.

Budja, M., 2015. Archaeology and rapid climate changes: from the collapse concept to a panarchy interpretive model. Documenta Praehistorica XLII, 171-184.

Cacho, I., Grimalt, J.O., Canals, M., Sbaffi, L., Shackleton, N.J., Schonfeld, J., Zahn, R., 2001. Variability of the western Mediterranean Sea surface temperature during the last 25,000 years and its connection with the Northern Hemisphere climatic changes. Paleoceanography 16, 40-52.

Cacho, I., Grimalt, J.O., Pelejero, C., Canals, M., Sierro, F.J., Flores, J.A., Shackleton, N., 1999. Dansgaard-Oeschger and heinrich event imprints in Alboran Sea paleotemperatures. Paleoceanography 14, 698-705.

Cacho, I., Grimalt, J.O., Sierro, F.J., Shackleton, N., Canals, M., 2000. Evidence for enhanced Mediterranean thermohaline circulation during rapid climatic coolings. Earth and Planetary Science Letters 183, 417-429.

Carletti, C., Sciurpi, F., Pierangioli, L., 2014. The energy upgrading of existing buildings: window and shading device typologies for energy efficiency refurbishment. Sustainability 6, 5354-5377.

Casford, J.S.L., Abu-Zied, R., Rohling, E.J., Cooke, S., Boessenkool, K.P., Brinkhuis, H., De Vries, C., Wefer, G., Geraga, M., Papatheodorou, G., Croudace, I., Thomson, J., Wells, N.C., Lykousis, V., 2001. Mediterranean climate variability during the Holocene. Mediterranean Marine Science 2, 45-55.

Casford, J.S.L., Rohling, E.J., Abu-Zied, R.H., Fontanier, C., Jorissen, F.J., Leng, M.J., Schmiedl, G., Thomson, J., 2003. A dynamic concept for eastern Mediterranean circulation and oxygenation during sapropel formation. Palaeogeography Palaeoclimatology Palaeoecology 190, 103-119. 
Cheng, H., Sinha, A., Verheyden, S., Nader, F.H., Li, X.L., Zhang, P.Z., Yin, J.J., Yi, L., Peng, Y.B., Rao, Z.G., Ning, Y.F., Edwards, R.L., 2015. The climate variability in northern Levant over the past 20,000 years. Geophysical Research Letters 42, 8641-8650.

Clare, L., 2016. Culture Change and Continuity in the Eastern Mediterranean during Rapid Climate Change. Assessing the vulnerability of Late Neolithic communities to a "Little Ice Age" in the seventh millennium cal B.C. Kölner Studien zur Prähistorischen Archäologie 7. Verlag Marie Leidorf.

Clare, L., Rohling, E.J., Weninger, B., Hilpert, J., 2008. Warfare in Late Neolithic/Early Chalcolithic Pisidia, southwestern Turkey. Climate induced social unrest in the late 7th millennium calBC, In: Budja, M. (Ed.), Documenta Praehistorica XXXV, 65-92.

Clarke, J., Brooks, N., Banning, E.B., Bar-Matthews, M., Campbell, S., Clare, L., Cremaschi, M., di Lernia, S., Drake, N., Gallinaro, M., Manning, S., Nicoll, K., Philip, G., Rosen, S., Schoop, U.D., Tafuri, M.A., Weninger, B., Zerboni, A., 2016. Climatic changes and social transformations in the Near East and North Africa during the 'long' 4th millennium BC: A comparative study of environmental and archaeological evidence. Quaternary Science Reviews 136, 96-121.

Climatedata (last visited 1-03-2018). https://www.climatedata.eu/

Climatemps.alexandroupoli (last visited 1-03-2018).

http://www.alexandroupoli.climatemps.com

$$
\text { Climatemps.crete (last visited 1-03-2018). http://www.crete.climatemps.com }
$$

Climatemps.haifa (last visited 1-03-2018). http://www.haifa.climatemps.com

Climatemps.plovdiv (last visited 1-03-2018). http://www.plovdiv.climatemps.com

Cline, E.H., 2014. 1177 B.C.: the year civilization collapsed. Princeton University Press, Princeton U.S.A, p. 237. ISBN978-0691-14089-6.

CNN WEATHER, 2001. Posted: December 19, 8:53 AM EST (1353 GMT). http://archives. cnn.com/2001/WEATHER/12/19/greece.romania/index. html

Constantin, S., Bojar, A. V., Lauritzen, S. E., and Lundberg, J., 2007. Holocene and Late Pleistocene climate in the sub-Mediterranean continental environment: A speleothem record from Poleva Cave (Southern Carpathians, Romania). Palaeogeography Palaeoclimatology Palaeoecology 243, 322-338.

Coulter, D., 2012. Europe hammered by winter, is North America next? https://science.nasa.gov/science-news/science-at-nasa/2012/16feb_deepfreeze Dailymail. http://www.dailymail.co.uk/news/article-2260223/Jerusalem-hit-worstsnowstorm-TWENTY-YEARS-inches-falls-Holy-City-closing-roads-schools.html

Dayan, U., Lifshitz-Goldreich, B., Pick, K., 2002. Spatial and structural variation of the atmospheric boundary layer during summer in israel-profiler and rawinsonde measurements. Journal of Applied Meteorology 41, 447-457.

Dayan, U., Ricaud, P., Zbinden, R., Dulac,F., 2017. Atmospheric pollution over the eastern Mediterranean during summer - a review. Atmospheric Chemistry and Physics 17, 13233-13263.

Dayan, U., Rodnizki, J., 1999. The temporal behavior of the atmospheric boundary layer in Israel. Journal of Applied Meteorology 38, 830-836.

Dean, J.R., Jones, M.D., Leng, M.J., Sloane, H.J., Roberts, C.N., Woodbridge, J., Swann, G.E.A., Metcalfe, S.E., Eastwood, W.J., Yigitbasioglu, H., 2013. Palaeo-seasonality of the last two 
1125

1126

1127

1128

1129

1130

1131

1132

1133

1134

1135

1136

1137

1138

1139

1140

1141

1142

1143

1144

1145

1146

1147

1148

1149

1150

1151

1152

1153

1154

1155

1156

1157

1158

1159

1160

1161

1162

1163

1164

1165

1166

1167

1168 millennia reconstructed from the oxygen isotope composition of carbonates and diatom silica from Nar Golu, central Turkey. Quaternary Science Reviews 66, 35-44.

Dean, J.R. Jones, M.D., Leng, M.J., Noble, S.R., Metcalfe, S.E., Sloane, H.J., Sahy, D., Eastwood, W.J., Roberts, C.N., 2015. Eastern Mediterranean hydroclimate over the late glacial and Holocene, reconstructed from the sediments of Nar lake, central Turkey, using stable isotopes and carbonate mineralogy. Quaternary Science Reviews 124, 162174.

Dirican, A., Ünal, S., Acar, Y., Demircan, M., 2005. The temporal and seasonal variation of H-2 and 0-18 in atmospheric water vapour and precipitation from Ankara, Turkey in relation to air mass trajectories at Mediterranean basin. In: Isotopic composition of precipitation in the Mediterranean Basin in relation to air circulation patterns and climate-Final report of a coordinated research project 2000-2004. IAEA-TECDOC1453, pp. 191-214, IAEA, Austria.

Dotsika, E., Lykoudis, S., Poutoukis, D., 2010. Spatial distribution of the isotopic composition of precipitation and spring water in Greece. Global and Planetary Change 71, 141-149.

Feurdean, Angelica, Stefan Klotz, Volker Mosbrugger, and Barbara Wohlfarth, 2008. Pollen-based quantitative reconstructions of Holocene climate variability in NW Romania, Palaeoclimatology Palaeogeography Palaeoecology 260, 494-504.

Fiedel, S.J., Anthony, D.W., 2003. Deerslayers, pathfinders and Icemen. Origins of the European Neolithic as seen from the frontier. In: Rockman, M., Steele, J. (eds.),

Colonization Unfamiliar Landscapes: the Archaeology of Adaptation. Routledge, pp. 144168.

Floodlist. http://floodlist.com/asia/heavy-rainfall-floods-israel

Frigola, J., Moreno, A., Cacho, I., Canals, M., Sierro, F.J., Flores, J.A., Grimalt, J.O., Hodell, D.A., Curtis, J.H., 2007. Holocene climate variability in the western Mediterranean region from a deepwater sediment record. Paleoceanography 22, PA2209, 10.1029/2006PA001307.

Fuller, D.Q., Asouti, E., Purugganan, M.D., 2012. Cultivation as slow evolutionary entanglement: Comparative data on rate and sequence of domestication. Veg Hist Archaeobot 21,131-145.

Galvin, J., Black, I., Priestley, D., 2011. Mesoscale weather features over the Mediterranean: Part 1. Weather 66, 72-78.

Ganot, M., Yair, Y., Price, C., Ziv, B., Sherez, Y., Greenberg, E., Devir, A., Yaniv, R., 2007. First detection of transient luminous events associated with winter thunderstorms in the eastern Mediterranean. Geophysical Research Letters 34, L12801, doi:10.1029/2007GL029258.

Gat, J.R., 1996. Oxygen and hydrogen isotopes in the hydrological cycle. Annual Review of Earth and Planetary Sciences 24, 225-262.

Gat, J.R., Ben-Mair, R., Yam, R., Yakir, D., Wernli, H., 2005. The isotope composition of atmospheric waters in Israel's coastal plain. In: Isotopic composition of precipitation in the Mediterranean Basin in relation to air circulation patterns and climate-Final report of a coordinated research project 2000-2004. IAEA-TECDOC-1453, pp. 99-114, IAEA, Austria. 
Gebel , H.G.K., 2009. The Intricacy of Neolithic Rubble Layers. The Ba'ja, Basta, and 'Ain Rahub evidence. In: (eds. Gebel, H.G.K. an Rollefson, G.O.). Special Issue on Rubble Layers and Rapid Climate Change, Neo-Lithics 1/09, 33-46.

Gkinis, V., Simonsen, S.B., Buchardt, S.L., White, J.W.C., Vinther, B.M., 2014. Water isotope diffusion rates from the NorthGRIP ice core for the last 16,000 years - Glaciological and paleoclimatic implications. Earth and Planetary Science Letters 405, 132-141.

Gogou, A., Triantaphyllou, M., Xoplaki, E., Izdebski, A., Parinos, C., Dimiza, M., Bouloubassi, I., Luterbacher, J., Kouli, K., Martrat, B., Toreti, A., Fleitmann, D., Rousakis, G., Kaberi, H., Athanasiou, M., Lykousis, V., 2016. Climate variability and socioenvironmental changes in the northern Aegean (NE Mediterranean) during the last 1500 years. Quaternary Science Reviews 136, 209-228.

Gonfiantini, R., 1986. Environmental isotopes in lake studies. In: Fritz, P., Fontes, J.C., Handbook of environmental isotope geochemistry, pp. 113-168, Elsevier, New York.

Grunewald, K., Scheithauer, J., 2010. Europe's southernmost glaciers: response and adaptation to climate change. Journal of Glaciology 56, 129-142.

Guilaine J., 2001. La diffusion de l'agriculture en Europe: une hypothese arythmique. Zephyrus 53, 267-272.

Heun, M., Abbo, S., Kev-Yadun, Gopher, A., 2012. A critical review of the protracted domestication model for Near-Eastern founder crops: linear regression, log-distance gene flow, archaeological and archaeobotanical evidende. Journal of Experimental Botany 63, 4333-4341.

Hillman, G.C., Davies, M.S., 1990. Domestication rates in wild type wheats and barley under primitive cultivation. Biological Journal of the Linnean Society 39, 39-78.

Hoefs, J., 1996. Stable isotope geochemistry: fourth completely revised, updated, and enlarged edition, 201 pp. Springer-Verlag, Berlin.

Honne, B.I., Heun, M., 2009. On the domestication genetics of self-fertilizing plants. Vegetation History and Archaeobotany 18, 269-272.

Horejs, B., Milić, B., Ostmann, F., Thanheiser, U., Weninger, B., Galik, A., 2015. The Aegean in the Early 7th Millennium BC: Maritime Networks and Colonization. Journal of World Prehistory 28, 289-330.

Hughes, P.D., 2014. Little Ice Age glaciers in the Mediterranean mountains, Méditerranée, 122, 63-97.

Incarbona, A., Martrat, B., Mortyn, P.G., Sprovieri, M., Ziveri, P., Gogou, A., Jordà, G., Luterbacher, J., Lagnone, L., Marino, G., Rodríguez-Sanz, L., Triantaphyllou, M., Di Stefano, E., Grimalt, J.O., Tranchida, G., Sprovieri, R., Mazzola, S., 2016. Mediterranean circulation perturbations over the last five centuries: Relevance to past Eastern Mediterranean Transient-type events. Scientific Reports 6: 29623, DOI: 10.1038/srep29623, 1-10.

Israelnationalnews. http://www.israelnationalnews.com/News/News.aspx/187927 Jones, M.D., Roberts, C.N., Leng, M.J., Türkeş, M., 2006. A high-resolution late Holocene lake isotope record from Turkey and links to North Atlantic and monsoon climate. Geology 34, 361-364.

Josey, S.A., Somot, S., Tsimplis, M., 2011. Impacts of atmospheric modes of variability on Mediterranean Sea surface heat exchange. Journal of Geophysical Research-Oceans 116, C02032, doi:10.1029/2010JC006685. 
1214

1215

1216

1217

1218

1219

1220

1221

1222

1223

1224

1225

1226

1227

1228

1229

1230

1231

1232

1233

1234

1235

1236

1237

1238

1239

1240

1241

1242

1243

1244

1245

1246

1247

1248

1249

1250

1251

1252

1253

1254

1255

1256

1257
Kagan, E.J., Langgut, D., Boaretto, E., Neumann, F.H., Stein, M., 2015. Dead Sea levels during the Bronze and Iron Ages. Radiocarbon 57, 237-252.

Kaniewski, D., Paulissen,E., Van Campo, E., Weiss, H., Otto, T., Bretschneider, T., Van Lerberghe, K., 2010. Late second-early first millennium BC abrupt climate changes in coastal Syria and their possible significance for the history of the Eastern Mediterranean. Quaternary Research 74, 207-215

Kaniewski, D., Marriner, N., Ilan, D., Morhange, C., Thareani, V., Van Campo, E., 2017. Climate change and water management in the biblical city of Dan. Science Advances, 3: e1700954, 1-8.

Kotthoff, U., Pross, U., Müller, U.C., Peyron, O., Schmiedl, G., Schultz, H., Bordon, A., 2008. Climate dynamics in the borderlands of the Aegean Sea during formation of sapropel S1 deduced from a marine pollen record. Quaternary Science Reviews 27, 832-845.

Krauß, R., Marinova, E., De Brue, H., Weninger, B., 2017. The rapid spread of early farming from the Aegean into the Balkans via the Sub-Mediterranean-Aegean Vegetation Zone. Quaternary International xxx, 1-8 (in press). doi.org/10.1016/j.quaint.2017.01.019

Krichak, S. O., Alpert, P., and Dayan, M., 2004. The role of atmospheric processes associated with Hurricane Olga in the December 2001 Floods in Israel. Journal of Hydrometeorology 5, 1259-1270.

Kuhlemann, J., Rohling, E.J., Kumrei, I., Kubik, P., Ivy-Ochs, S., Kucera, M., 2008. Regional synthesis of Mediterranean atmospheric circulation during the Last Glacial Maximum. Science 321, 1338-1340.

Kuhnt, T., Schmiedl, G., Ehrmann, W., Hamann, Y., Hemleben, C., 2007. Deep-sea ecosystem variability of the Aegean Sea during the past 22 kyr as revealed by Benthic Foraminifera. Marine Micropaleontology 64, 141-162.

Kuper, R. and Kröpelin, S., 2006. Climate-Controlled Holocene Occupation in the Sahara: Motor of Africa's Evolution. Science 313, 803-807.

Leaman, K.D., Schott, F.A., 1991. Hydrographic structure of the convection regime in the Gulf of Lions: Winter 1987. Journal of Physical Oceanography 21, 575-598.

Lespez, L., Tsirtsoni, Z., Darcque, P., Koukouli-Chryssanthraki, H., Malamidou, D., Treuil, R., Oberlin, C. , 2013. The lowest levels at Dikili Tash, northern Greece: a missing link in the Early Neolithic of Europe. Antiquity 87, 30-45.

Linstädter, J., Broich, M., Weninger, B., 2016. Defining the Early Neolithic of the Eastern Rif, Morocco - Spatial distribution, chronological framework and impact of environmental changes. Quaternary International XXX, 1-11.

Lionello, P., Malanotte-Rizzoli, P., Boscolo, R., 2006. Mediterranean climate variability, Vol. 4., Elsevier, 438 pp., ISBN9780444521705

Litt, T., Ohlwein, C., Neumann, F.H., Hense, A., Stein, M., 2012. Holocene climate variations in the Levant from the Dead Sae pollen record. Quaternary Science Reviews 49, 95-105.

Lolis, C.J., Bartzokas, A., Katsoulis, B.D., 2002. Spatial and temporal 850 hPA air temperature and sea-surface temperature covariances in the Mediterranean region and their connection to atmospheric circulation. International Journal of Climatology 22, 663-676. 
Luterbacher, J., Xoplaki, E., Casty, C., Wanner, H., Pauling, A., Küttel, M., Ruthishauser, T., Brönnimann, S., Fischer, E., Fleitmann, D., González-Rouco, F.J., García-Herrera, R., Barriendos, M., Rodrigo, F., Gonzalez-Hidalgo, J.C., Angel Saz, M., Gimeno, L., Ribera, P., Brunet, M., Paeth, H., Rimbu, N., Felis, T., Jacobeit, J., Dünkeloh, A., Zorita, E., Guiot, J., Türkes, M., Joao Alcoforado, M., Trigo, R., Wheeler, D., Tett, S., Mann, M.E., Touchan, R., Shindell, D., Silenzi, S., Montagna, P., Camuffo, D., Meriotti, A., Nanni, T., Brunetti, M., Maugeri, M., Zerefos, C., De Zolt, S., Lionello, P., 2006. In: Lionello, P., Malanotte-Rizzoli, P., Boscolo, R., Eds. The Mediterranean Climate: An Overview of the Main Characteristics and Issues (Elsevier, Amsterdam, 2006), pp. 27-148.

Maheras, P., Xoplaki, E., Davies, T., Martin-Vide, J., Bariendos, M., Alcoforado, M.J., 1999. Warm and cold monthly anomalies across the Mediterranean basin and their relationship with circulation; 1860-1990. International Journal of Climatology 19, 16971715.

Majoube, M., 1971. Fractionnement en oxygène 18 et deuterium entre l'eau et sa vapeur. Journal de Chimie Physique 10, 1423-1436.

Mangini, A., Verdes, P., Spotl, C., Scholz, D., Vollweiler, N., Kromer, B., 2007. Persistent influence of the North Atlantic hydrography on central European winter temperature during the last 9000 years. Geophysical Research Letters 34, L02704, doi:10.1029/2006GL028600.

Marino, G., Rohling, E.J., Sangiorgi, F., Hayes, A., Casford, J.L., Lotter, A.F., Kucera, M., Brinkhuis, H., 2009. Early and middle Holocene in the Aegean Sea: interplay between high and low latitude climate variability. Quaternary Science Reviews 28, 3246-3262. Mariolopoulos, E.G., 1961. An outline of the climate of Greece. Publications of the Meteorological Institute of the University of Athens 6, $51 \mathrm{pp}$.

Mayewski, P.A., Meeker, L.D., Twickler, M.S., Whitlow, S., Yang, Q.Z., Lyons, W.B., Prentice, M., 1997. Major features and forcing of high-latitude northern hemisphere atmospheric circulation using a 110,000-year-long glaciochemical series. Journal of Geophysical Research-Oceans 102, 26345-26366.

Mayewski, P.A., Rohling, E.E., Stager, J.C., Karlen, W., Maasch, K.A., Meeker, L.D., Meyerson, E.A., Gasse, F., van Kreveld, S., Holmgren, K., Lee-Thorp, J., Rosqvist, G., Rack, F., Staubwasser, M., Schneider, R.R., Steig, E.J., 2004. Holocene climate variability. Quaternary Research 62, 243-255.

Meeker, L.D., Mayewski, P.A., 2002. A 1400-year high-resolution record of atmospheric circulation over the North Atlantic and Asia. Holocene 12, 257-266.

Mercone, D., Thomson, J., Abu-Zied, R.H., Croudace, I.W., Rohling, E.J., 2001. Highresolution geochemical and micropalaeontological profiling of the most recent eastern Mediterranean sapropel. Marine Geology 177, 25-44.

Merlivat, L., Jouzel, J. 1979. Global climatic interpretation pf the deuterium-oxygen 18 relationship for precipitation. Journal of Geophysical Research 84, 5029-5033.

Migowski, C., Stein, M., Prasad, S., Negendank, J.F.W., Agnon, A, 2006. Holocene climate variability and cultural evolution in the Near East from the Dead Sea sedimentary record. Quaternary Research 66, 421-431.

Moreno-Chamarro, E., Zanchettin, D., Lohmann, K., Luterbacher, J., Junclaus, J.H., 2017. Winter amplification of the European Little Ice Age cooling by the subpolar gyre.

Scientific Reports 7: 9981, DOI:10.1038/s41598-017-07969-0, 1-8. 
Muschitiello, F., Schwark, L., Wolfarth, B., Sturm, C., Hammarlund, D., 2013. New evidence of Holocene atmospheric circulation dynamics based on lake sediments from southern Sweden: a link to the Siberian High. Quaternary Science Reviews 77, 113-124. Nieuwenhuyse, 0., 2017. Globalizing the Halaf. In: Tamar Hodos (ed.). The Routledge Handbook of Archaeology and Globalization. Routledge. London and New York. 839854.

O'Brien, S.R., Mayewski, P.A., Meeker, L.D., Meese, D.A., Twickler, M.S., Whitlow, S.I., 1995. Complexity of Holocene climate as reconstructed from a Greenland ice core. Science 270, 1962-1964.

Panagiotopoulos F, Shagedanova M, Hannachi A, Stephenson D., 2005. Observed trends and teleconnections of the Siberian High: a recently declining center of action. Journal of Climate 18, 1411-1422.

Peyron, O., Goring, S., Dormoy, I., Kotthoff, U., Pross, J., de Beaulieu, J.L., DrescherSchneider, R., Vanniere, B., Magny, M., 2011. Holocene seasonality changes in the central Mediterranean region reconstructed from the pollen sequences of Lake Accesa (Italy) and Tenaghi Philippon (Greece). Holocene 21, 131-146.

Plicht, J. van der, Akkermans, P., Nieuwenhuyse, O., Kaneda, A., Russell, A., 2011. Tell Sabi Abyad, Syria: Radiocarbon Chronology, Cultural Change, and the 8.2 Ka Event. Radiocarbon 53, 229-243.

Poulos, S.E., Drakopoulos, P.G., Collins, M.B., 1997. Seasonal variability in sea surface oceanographic conditions in the Aegean Sea (Eastern Mediterranean): an overview. Journal of Marine Systems 13, 225-244.

Pross, J., Kotthoff, U., Muller, U.C., Peyron, O., Dormoy, I., Schmiedl, G., Kalaitzidis, S., Smith, A.M., 2009. Massive perturbation in terrestrial ecosystems of the Eastern Mediterranean region associated with the 8.2 kyr BP climatic event. Geology 37, 887890.

Revel, M., Ducassou, E., Frousset, F.E., Bernasconi, S.M., Migeon, S., Revillon, S., Mascle, J., Murat, A., Zaragosi, S., Bosch, D., 2010. 100,000 Years of African monsoon variability recorded in sediments of the Nile margin. Quaternary Science Reviews 29, 1342-1362.

Roberts, N., Allcock, S.L., Arnaud, F., Dean, J.R., Eastwood, W.J., Jones, M.D., Leng, M.J., Metcalfe, S.E., Malet, E., Woodbridge, J., Yigitbasioglu, H., 2016. A tale of two lakes: a multi-proxy comparison of Lateglacial and Holocene environmental change in Cappadocia, Turkey. Journal of Quaternary Science 31, 348-362.

Roberts, N., Brayshaw, D., Kuzucuoglu, C., Perez, R., Sadori, L., 2011. The mid-Holocene climatic transition in the Mediterranean: Causes and consequences. Holocene 21, 3-13.

Roether, W., Manca, B.B., Klein, B., Bregant, D., Georgopoulos, D., Beitzel, V., Kovacevic, V., Luchetta, A., 1996. Recent changes in eastern Mediterranean deep waters. Science 271, 333-335.

Rohling, E.J., 1999. Environmental control on Mediterranean salinity and $\delta^{18} 0$. Paleoceanography 14, 706-715.

Rohling, E.J., 2013. Quantitative assessment of glacial fluctuations in the level of Lake Lisan, Dead Sea rift. Quaternary Science Reviews 70, 63-72.

Rohling, E.J., 2016. Of lakes and fields: A framework for reconciling palaeoclimatic drought inferences with archaeological impacts. Journal of Archaeological Science 73, 17-24. 
Rohling, E.J., Casford, J., Abu-Zied, R., Cooke, S., Mercone, D., Thomson, J., Croudace, I., Jorissen, F.J., Brinkhuis, H., Kallmeyer, J., Wefer, G., 2002a. Rapid Holocene climate changes in the eastern Mediterranean. In Hassan, F. (ed.) Droughts, Food and Culture: Ecological Change and Food Security in Africa's Later Prehistory, Kluwer Academic/Plenum Publishers, London, pp. 35-46.

Rohling, E.J., Hayes, A., Mayewski, P.A., Kucera, M., 2009. Holocene climate variability in the eastern Mediterranean, and the End of the Bronze Age. In: Bachhuber, C. and Roberts, R.G. (eds.) Forces of Transformation: The End of the Bronze Age in the Mediterranean. BANEA Publication Series 1, Oxbow Books, Oxford, ISBN-13: 978-184217-332-9, pp. 2-5.

Rohling, E.J., Jorissen, F.J., DeStigter, H.C., 1997. 200 year interruption of Holocene sapropel formation in the Adriatic Sea. Journal of Micropalaeontology 16, 97-108.

Rohling, E.J., Marino, G., Grant, K.M., 2015. Mediterranean climate and oceanography, and the periodic development of anoxic events (sapropels). Earth Science Reviews 143, 62-97.

Rohling, E.J., Mayewski, P.A., Abu-Zied, R.H., Casford, J.S.L., Hayes, A., 2002b. Holocene atmosphere-ocean interactions: records from Greenland and the Aegean Sea. Climate Dynamics 18, 587-593.

Rohling, E.J., Mayewski, P.A., Challenor, P., 2003. On the timing and mechanism of millennial-scale climate variability during the last glacial cycle. Climate Dynamics 20, 257-267.

Rohling, E.J., Pälike, H., 2005. Centennial-scale climate cooling with a sudden cold event around 8,200 years ago. Nature 434, 975-979.

Rohling, E.J., Sprovieri, M., Cane, T., Casford, J.S.L., Cooke, S., Bouloubassi, I., Emeis, K.C., Schiebel, R., Rogerson, M., Hayes, A., Jorissen, F.J., Kroon, D., 2004. Reconstructing past planktic foraminiferal habitats using stable isotope data: a case history for Mediterranean sapropel S5. Marine Micropaleontology 50, 89-123.

Rollefson, G.O., 2009. Slippery Slope: The Late Neolithic Rubble Layer in the Southern Levant. In: (eds. Gebel, H.G.K. an Rollefson, G.O.). Special Issue on Rubble Layers and Rapid Climate Change, Neo-Lithics 1/09, 12-18.

Rozanski, K., Araguas-Araguas, L, Gonfiantini, R., 1993. Isotopic patterns in modern global precipitation. In: Swart, P.K., Climate change in continental isotopical records. Geophysical Monograph Series 78, pp.1-36. American Geophysical Union, Washington D.C.

Saaroni, H., Bitan, A., Alpert, P., Ziv, B., 1996. Continental polar outbreaks into the Levant and eastern Mediterranean. International Journal of Climatology 16, 1175-1191.

Saaroni, H., Halfon, N., Ziv, B., Alpert, P., and Kutiel, H., 2010. Links between the rainfall regime in Israel and location and intensity of Cyprus lows. International Journal of Climatology 30, 1014-1025.

Schemmel, F., Niedermeyer, E.M., Koutsodendris, A., Pross, J., Fiebig, J., Mulch, A., 2017. Paleohydrological changes in the Eastern Mediterranean region during the early to midHolocene recorded in plant wax n-alkane distributions and delta C-13(TOC) - New data from Tenaghi Philippon, NE Greece. Organic Geochemistry 110, 100-109.

Schemmel, F., Niedermeyer, E.M., Schwab, V.F., Gleixner, G., Pross, J., Mulch, A., 2016. Plant wax delta D values record changing Eastern Mediterranean atmospheric 
circulation patterns during the 8.2 kyr BP climatic event. Quaternary Science Reviews 133, 96-107.

Schemmel, F., Niedermeyer, E.M., Koutsodendris, A., Pross, J., Fiebig, J., Mulch, A., 2017. Paleohydrological changes in the Eastern Mediterranean region during the early to midHolocene recorded in plant wax n-alkane distributions and $\delta^{13} \mathrm{C}_{\mathrm{TOC}}-\mathrm{New}$ data from Tenaghi Philippon, NE Greece. Organic Geochemistry 110, 100-109.

Schmiedl, G., Kuhnt, T., Ehrmann, W., Emeis, K.-C., Hamann, Y., Kotthoff, U., Dulski, O., Pross, J., 2010. Climatic Forcing of eastern Mediterranean deep-water formation and benthic ecosystems during the past 22000 years. Quaternary Science Reviews 29, 3006-3020.

Seidel, D.J., Zhang, Y.H., Beljaars, A., Golaz, J.C., Jacobson, A.R., Medeiros, B., 2012. Climatology of the planetary boundary layer over the continental United States and Europe. Journal of Geophysical Research-Atmospheres 117, D17106, doi:10.1029/2012JD018143

Shamir, E., Rimmer, A., Georgakakos, K.P., 2016. The Use of an Orographic Precipitation Model to Assess the Precipitation Spatial Distribution in Lake Kinneret Watershed. Water 8, 591, doi:10.3390/w8120591

Sharifi, A., Pourmand, A., Canuel, E.A., Ferer-Tyler, E., Peterson, L.C., Aichner, B., Feakins, S.J., Daryaee, T., Djamali, M., Naderi Beni, A., Lahijani, H.A.K., Swart, P.K., 2015. Abrupt climate variability since the last deglaciation based on a high-resolution, multi-proxy peat record from NW Iran: The hand that rocked the Cradle of Civilization. Quaternary Science Reviews 123, 215-230.

Sharon, D., and Kutiel, H., 1986. The distribution of rainfall intensity in Israel, its regional and seasonal variations and its climatological evaluation. International Journal of Climatology 6, 277-291.

Stein, M., and Litt, T., 2013. Reply to comment by Christoph Zielhofer and Bernhard Weninger on the article: "Holocene climate variability in the Levant from the Dead Sea pollen record" by Litt et al. Quaternary Science Reviews 49 (2012) 95-105. Quaternary Science Reviews 59, 113-114.

Tarolli, P., Borga, M., Morin, E., and Delrieu, G., 2012. Analysis of flash flood regimes in the North-Western and South-Eastern Mediterranean regions. Natural Hazards Earth System Science 12, 1255-1265.

Theocharis, A., 1989. Deep water formation and circulation in the Aegean Sea. In: Charnock, H. (Ed.), Reports in Meteorology and Oceanography 40, I, pp. 335-359.

Thomas, E.R., Wolff, E.W., Mulvaney, R., Steffensen, J.P., Johnsen, S.J., Arrowsmith, C., White, J.W.C., Vaughn, B., Popp, T., 2007. The 8.2 ka event from Greenland ice cores. Quaternary Science Reviews 26, 70-81.

Timesofisrael. http://www.timesofisrael.com/heavy-downpour-hits-israel-overnight/ Tolika, K., Maheras, P.,Pytharoulis, I., Anagnostopoulou, C., 2014. The anomalous low and high temperatures of 2012 over Greece-An explanation from a meteorological and climatological perspective. Natural Hazards Earth System Science 14, 501-507.

Torfstein, A., Goldstein, S.L., Kagan, E., Stein, M., 2013a. Integrated multi-site U-Th chronology of the last glacial Lake Lisan. Geochimica et Cosmochimica Acta 104, 210231. 
Torfstein, A., Goldstein, S.L., Stein, M., Enzel, Y., 2013b. Impacts of abrupt climate changes in the Levant from last glacial Dead Sea levels. Quaternary Science Reviews 69, 1-7.

Tubi, A., Dayan, U., 2013. The Siberian High: teleconnections, extremes and association with the Icelandic Low. International Journal Of Climatology 33, 1357-1366.

Tyrlis, E., Lelieveld, J., Steil., B., 2013. The summer circulation over the eastern Mediterranean and the Middle East: influence of the South Asian monsoon. Climate Dynamics 40, 1103-1123.

Tzedakis, P.C., 2007. Seven ambiguities in the Mediterranean palaeoenvironmental narrative. Quaternary Science Reviews 26, 2042-2066.

Valsecchi, V., Sanchez Goñi, M., Londeix, L., 2012. Vegetation dynamics in the Northeastern Mediterranean region during the past $23000 \mathrm{yr}$ : insights from a new pollen record from the Sea of Marmara. Climate of the Past 8, 1941-1956.

Van Andel, T.H., Runnels, C.N., 1995. The earliest farmers in europe. Antiquity 69, 481500.

Vardavas, I.M., Papamastorakis, J., Fountoulakis, A., Manousakis, M., 1997. Water resources in the desertification-threatened Messara Valley of Crete: estimation of potential lake evaporation. Ecological Modelling 102, 363-374.

Velaoras, D., Papadopoulos, V.P., Kontoyiannis, H., Papageorgiou, D.K., Pavlidou, A., 2017. The response of the Aegean Sea (Eastern Mediterranean) to the extreme 20162017 winter. Geophysical Research Letters 44, 9416-9423.

Weatherspark (last visited 1-03-2018). https://weatherspark.com/averages/32207/Santorini-Thira-South-Aegean-Greece

Weiberg, E., Unkel, I., Kouli, K., Holmgren, K., Avramidis, P., Bonnier, A., Dibble, F., Finné, M., Izdebski, A., Katrantsiotis, C., Stocker, S.R., Andwinge, M., Baika, K., Boyd, M., Heymann, C., 2016: The socio-environmental history of the Peloponnese during the Holocene: Towards an integrated understanding of the past. Quaternary Science Reviews 136, 40-65.

Weiss, H., 2000. Beyond the Younger Dryas: collapse as adaptation to abrupt cli $\neg$ mate change in ancient West Asia and the eastern Mediterranean. In G. Bawden and M. Reycraft (eds), Environmental Disaster and the Archaeology of Human Response. Anthropological Papers 7. Albuquerque, NM: Maxwell Museum of Anthropology, 75- 98. Weiss, H. 2017 (ed.). Megadrought and Collapse. From Early Agriculture to Angkor. Oxford. Oxford University Press.

Weninger, B., Alram-Stern, E., Bauer, E., Clare, L., Danzeglocke, U., Jöris, O., Kubatzki, C., Rollefson, G., Todorova, H., van Andel, T, 2006. Climate Forcing Due to the 8200 Cal yr BP Event Observed at Early Neolithic Sites in the Eastern Mediterranean. Quaternary research 66, 401-420.

Weninger, B., Clare, L., Gerritsen, F., Horejs, B., Krauß, R., Linstädter, J., Özbal, R., Rohling, E.J., 2014. Neolithisation of the Aegean and Southeast Europe during the 6600-6000 calBC period of Rapid Climate Change. Documenta Praehistorica XLI, 1-31.

Weninger, B., Clare, L., Rohling, E.J., Bar-Yosef, O., Boehner, U., Budja, M., Bundschuh, M., Feurdean, A., Gebel, H.G., Joeris, O., Lindstaedter, J., Mayewski, P., Muehlenbruch, T., Reingruber, A., Rollefson, G., Schyle, D., Thissen, L., Todorova, H., Zielhofer, C., 2009. The 
impact of rapid climate change on prehistoric societies during the Holocene in the Eastern Mediterranean. Documenta Praehistorica 36, 7-59.

Weninger, B., Harper, T., The Geographic Corridor for Rapid Climate Change in Southeast Europe and Ukraine, 2015. In: Svend Hansen, Pál Raczky, Alexandra Anders and Agathe Reingruber (Eds.), Neolithic and Copper Age between the Carpathians and the Aegean Sea. Chronologies and Technologies from the 6th to 4th Millennium BC. International Workshop Budapest 2012, Bonn: Rudolf Habelt, 485-515.

Weninger, B. 2017. Niche Construction and theory of agricultural conditions. Case studies in punctuated equilibrium. Documenta Praehistorica XLIV, 6-17.

Wittenberg, L., Kutiel, H., Greenbaum, N., Inbar, M., 2007. Short- term changes in the magnitude, frequency and temporal distribution of floods in the Eastern Mediterranean region during the last 45 years - Nahal Oren, Mt. Carmel, Israel. Geomorphology 84, 181-191.

WORLD WEATHER NEWS 2001. online: http://www.met. rdg.ac.uk/ brugge/world2001.html

Xoplaki, E., Maheras, P., Luterbacher, J., 2001. Variability of Climate in Meridional Balkans during the Periods 1675-1715 and 1780-1830 and its Impact on Human Life. Climatic Change 48, 581-615.

Yavuz, V., Akçar, N., Schlüchter, C. 2007. The Frozen Bosphorus and its Paleoclimatic Implications based on a Summary of the Historical Data. In: Yanko-Hombach, V., Gilbert, A.S., Panin, N., Dolukhanov, P.M. (eds), The Black Sea Flood Question: Changes in Coastline, Climate, and Human Settlement. Springer, Dordrecht, 633-649.

Zhang, X., Reed, J., Wagner, B., Francke, A., Levkov, Z., 2014. Lateglacial and Holocene climate and environmental change in the northeastern Mediterranean region: diatom evidence from Lake Dojran (Republic of Macedonia/Greece). Quaternary Science Reviews 103, 51-66.

Zielhofer, C., Weninger, B., 2013. Comment on: "Holocene climate variability in the Levant from the Dead Sea pollen record" by Litt, T., Ohlman, C., Neumann, F.H., Hense, A.,. Stein, M., [Quat.Sci.Rev.49 (2012) 95-105]. Quaternary Science Reviews 59, 112. Zielhofer, C., Clare, L., Rollefson, G., Wächter, S., Hoffmeister, D., Bareth, G., Roettig, C., Bullmann, H., Schneider, B., Berke, H., Weninger, B., 2012. The decline of the early Neolithic population center of 'Ain Ghazal and corresponding earth-surface processes, Jordan Rift Valley. Quaternary Research 78, 427-441.

Ziv, B., Dayan, U., Kushnir, Y., Roth, C., Enzel, Y., and Ziv, B., 2006. Regional and global atmospheric patterns governing rainfall in the southern Levant. International Journal of Climatology 26, 55-73. 